\title{
An Overview on Recent Developments in the Synthesis, Characterization and Properties of High Dielectric Constant Calcium Copper Titanate Nano-Particles
}

\author{
U.S.Rai1, Laxman Singh ${ }^{1}$, K.D.Mandal ${ }^{2 *}$ and Narsingh B. Singh ${ }^{3}$ \\ ${ }^{1}$ Department of Chemistry, Faculty of Science, Banaras Hindu University, Varanasi - 221005, U.P. (India) \\ ${ }^{2}$ Department of Chemistry, Indian Institute of Technology, Banaras Hindu University, Varanasi - 221005, U.P. (India) \\ ${ }^{3}$ Department of Chemistry and Biochemistry, University of Maryland Baltimore County, Baltimore, MD 21250, USA
}

Received: December 15, 2013; Accepted: May 05, 2014; Published: May 05, 2014

*Corresponding author: K.D Mandal, Department of Chemistry, Indian Institute of Technology, Banaras Hindu University, Varanasi-221005, U.P. (India), Tel: +91-542-6702868; Fax: +91-542-2368428; Email: kdmandal.apc@itbhu.ac.in

\begin{abstract}
The potential demand for miniaturization of electrical and electronic devices has raised a serious challenge for the development of capacitors with high dielectric constant and low loss. The high dielectric constant calcium copper titanate, $\mathrm{CaCu}_{3} \mathrm{Ti}_{4} \mathrm{O}_{12}$ (CCTO), and its isomorphs have attracted much attention for the development of promising capacitor materials for electronic industries. Improving the synthetic technology and dielectric properties of these materials is a current focus of research and development in the area of materials chemistry. Because of their improved properties due to size and structure, the nanometer-sized particles (with dimensions smaller than $100 \mathrm{~nm}$ ) have attracted considerable interest for a wide variety of applications, including electronics, ceramics and as catalysts. The wet chemical methods provide atomic level mixing of individual components and result in the formation of nano-crystalline materials at much lower temperature compared to solid state reactions. Many chemical methods, such as, sol-gel, co-precipitation, precursor solution technique, hydrothermal process, carbo-thermal reduction, microwave heating, spray pyrolysis, co-precipitation and microemulsion drying are already reported for the synthesis of CСTO ceramics. The present communication gives a current overview of the synthetic procedures used for the production of CСTO and doped derivatives. In addition to already established conventional routes of preparation, alternative procedures are also outlined.
\end{abstract}

Keywords: Calcium copper titanate; Synthesis of CCTO; Nanocrystalline; Sol-gel processing; Semi-wet route; Dielectric properties

\section{Introduction}

In the modern age of science there is continuous demand for miniaturization of electronic devices (cell phones, digital cameras, note book, computers, TV etc.) and there is continuous interest to develop capacitor materials with high dielectric constant and low loss for application to microelectronics, microwave, memory and capacitance based energy storage devices [9]. Electroceramic materials are considered essentials due to their excellent dielectric, piezoelectric and electromechanical properties, which are used in defense, aerospace and civil sectors such as aerospace, transducers and sensors and gyroscopes. The power capacitors are the passive critical components in aircraft instrumentation, missile systems, satellite positioning equipment, ignition systems, etc. to provide a static source of power in electrical distribution systems. Electrical energy storage plays a key role in mobile electronic devices, stationary power systems, hybrid electric vehicles and pulse power applications. In particular, there is a growing need for capacitors that can accumulate a large amount of energy and then deliver it nearly instantaneously. This kind of "pulse power" is needed for a variety of military and commercial applications. Dielectric materials can be used to store electrical energy in the form of charge separation when the electron distributions around constituent atoms or molecules are polarized by an external electric field. Requirement of an ideal capacitor material is that it should have (1) high dielectric constant $\left(10^{4}-10^{6}\right)(2)$ low dielectric loss ( $\left.\tan \delta=0.01-0.0001\right)$ (3) high thermal stability (stable up to $500^{\circ} \mathrm{C}$ ) and (4)no variation in dielectric constant with temperature and frequency of current in any region.Calcium copper titanate is a member of an oxide family whose general formula is $\mathrm{ACu}_{3} \mathrm{Ti}_{4} \mathrm{O}_{12}$. Depending on different values of a one can get different isomorphs of this family. When $\mathrm{A}$ is calcium,the corresponding compound will be $\mathrm{CaCu}_{3} \mathrm{Ti}_{4} \mathrm{O}_{12}$ and this compound was discovered by Deschanvres et al. [1]. This family was expanded and its accurate crystal structures were determined by Bochu et al. [2]. According to them this compound belongs to BCC system with Im3 space group and 7.391 $\AA$ unit cell length, and there are two formula units per unit cell of the compound. While two calcium atoms sit at the corners and body center of the cube and six copper atoms are located at its six face centers and twelve edge centers, the eight Ti atoms are present at the centers of the octahedron facing each other with bridging copper atoms bonded to oxygen. Recently, high resolution X-ray diffraction patterns and neutron diffraction studies by Adams et al. [3] in 2006 have shown that these compounds crystallize as perovskite structures where $\mathrm{TiO}_{6}$ octahedra are tilted to produce square-planer environment for each copper ion. This tilting alters the coordination environments of A-site cations, leading to a 4-coordinate square-planar environment for $\mathrm{Cu}$ and 
12-coordinate icosahedral environment for $\mathrm{Ca}$. It is the mismatch in size and bonding preferences of these two ions and titanium that drive the large octahedral tilting distortion. $\mathrm{ACu}_{3} \mathrm{Ti}_{4} \mathrm{O}_{12}$ type oxides with complex perovskite structure show high dielectric constant leading to many important applications. Presently we use $\mathrm{BaTiO}_{3}$ or relaxor ferroelectrics such as $\mathrm{Pb}\left(\mathrm{Mg}_{1 / 3} \mathrm{Nb}_{2 / 3}\right) \mathrm{O}_{3}$ [PMN], $\mathrm{Pb}\left(\mathrm{Zn}_{1 / 3} \mathrm{Nb}_{2 / 3}\right) \mathrm{O}_{3}$ [PZN], and $\mathrm{Pb}_{1-\mathrm{x}} \mathrm{La}_{\mathrm{x}}\left(\mathrm{Zr}_{1-\mathrm{y}} \mathrm{Ti}_{\mathrm{y}}\right) \mathrm{O}_{3}$ [PLZT], which are not environmentally friendly as capacitor materials (dielectric constant $\approx 1000-20,000$ ) [4]. Problems with $\mathrm{BaTiO}_{3}$ are that it is a ferroelectric perovskite which is quite unstable and shows phase transitions. Its dielectric constant being highly unstable with temperature (T), it is not suitable for use at an elevated temperature. For this reason, a thermally stable high dielectric constant calcium copper titanate, $\mathrm{CaCu}_{3} \mathrm{Ti}_{4} \mathrm{O}_{12}$ (CCTO), which belongs to $\mathrm{ACu}_{3} \mathrm{Ti}_{4} \mathrm{O}_{12}$ family, first reported by Subramanian et al. [5] in the year 2000 is the best choice. The very high dielectric constant $\left(\sim 10^{4}\right)$ exhibited by (CCTO), which is nearly constant in the temperature range, $100 \mathrm{~K}$ to $600 \mathrm{~K}$ makes it a promising material which can lead, to many important applications in microelectronics and memory devices as static dielectric constant of a material ultimately decides the degree of miniaturization. It may be widely used in the electronic industries to manufacture electronic components such as multilayer capacitor (MLCC), DRAMs (Dynamic Random Access Memory), microwave devices, electronic devices in automobiles and aircrafts. Despite the fact that much research work has been done to reveal nature and origin of the giant dielectric constant of ССТО ceramics, it still remains controversial and unsolved to date. At present, a possible explanation that an internal barrier layer capacitance (IBLC) model between the insulating grain boundaries and semiconducting grains, is widely accepted by the researchers. High dielectric constant values may be variously attributed to [6-8]:

1. The barrier layer capacitance arising at twin boundaries

2. Disparity in electrical properties between grain interiors and Grain boundaries

3. Space charge at interfaces between the sample and the electrode contacts

4. Polarizability contributions from lattice distortions

5. Differences in electrical properties due to internal domains

\section{Dipolar contributions from oxygen vacancies}

7. The role of $\mathrm{Cu}$ off-stoichiometry in modifying the polarization mechanisms

8. Cation disorder induced planer defects and associated in homogeneity.

A variety of methods [10-13] has been reported by several researchers to prepare this giant dielectric material. Among these the most adopted and traditional solid state reaction method lacks in terms of homogeneity of precursor materials. In addition, the process requires higher sintering temperature and longer sintering time for solid state diffusion to occur for single phase-formation. Therefore, the chemical methods resulting in good homogeneity in CCTO and their isomorphs at lower sintering temperature in shorter sintering time is the current approach for the synthesis of the best quality materials. With a view to obtain high dielectric constant and low loss CCTO, effect of substitution on it has been studied by various workers [1417] and they report wide variation in these values as a result of this exchange. Fang and Shiau [18] have studied the effect of sintering time from zero time to $20 \mathrm{hrs}$ at $1035{ }^{\circ} \mathrm{C}$ on the dielectric properties of CСTO and have found that it varies from 1000 to 18000 in this time duration. Driven by the needs, and the peculiar properties of nano-particles due to their small size and large surface area, various aspects of Ca- $\mathrm{Zn}$ exchange have been studied. For this CCTO and their isomorphs with zinc have been prepared by semi-wet route involving different sintering time. In addition, the effects of synthetic methods have also been studied. They were characterized by X-ray and TEM techniques and their dielectric properties were studied in the different temperature and frequency regions. Although a large number of papers [1923] have been published by authors on CCTO where cationic exchange reactions have been studied, in the present paper an overview of the summary of synthesis, characterization by X-rays and dielectric properties for systems giving nano-particles have been reported. In the absence of any review on the CCTO, in general, and ССТO nano-particles in particular, the present paper gives an account of recent development and latest information on calcium copper titanate which will be quite useful for the new workers in this area.

\section{Synthetic Routes of CCTO}

With a view to obtain high dielectric constant and low tangent loss calcium copper titanate, $\mathrm{Ca}, \mathrm{Cu}$, and Ti exchange was studied. ССTO and its substituted isomorphs have been synthesized by different methods, namely, (i) solid-state route (ii) chemical route (iii) combustion route and (iv) semi-wet route. These resultant products were characterized by X-ray and transmission electron microscopy (TEM) techniques. The dielectric constant and the corresponding dielectric loss of these electro-ceramics have been studied in the temperature range $100 \mathrm{~K}$ to $600 \mathrm{~K}$ at various frequencies. Assessment of the influence of the different processing parameters, such as, sintering time and sintering temperature on the dielectric properties were also studied.

\section{Dry method}

The perovskite oxides are generally synthesized by conventional solid-state route [13] or dry method. In this route, oxides of various cations with suitable liquid (acetone or ethanol) are mixed in stoichiometric ratio and ground to fine powder using a pestle-mortar. Dried mixed powder is calcined at a particular temperature for a certain period of time. The calcined powder is ground again and converted in to fine powder. An optimum amount of a suitable binder, polyvinyl alcohol (PVA) is added to the powder and mixed uniformly and then it is pressed in to a suitable shape. The resulting product is first heated slowly to a particular temperature to remove the binder and then the temperature of the sample is increased to a particular value and maintained at this value for certain duration for annealing. After 
annealing, the sample is cooled under controlled rate of cooling. The final resulting product is achieved by diffusion of metal ions at high temperature. Asystematic flow chart is shown in Figure 1.

\section{Wet methods}

The dry method used for the synthesis of CCTO requires relatively long reaction time and high temperature condition. In addition, some other secondary phases also appear during the synthesis because of limited atomic diffusion through micrometer sized grains. Therefore, repeated grinding, mixing and annealing is required at high temperature to attain chemical homogeneity.

However, this does not lead to chemical homogeneity at micro level in the end product. On the other hand, the wet chemical methods [24-26] provide atomic level mixing of individual components and result in the formation of nano-crystalline materials at much lower temperature compared to solid state reactions. There are many chemical methods, such as, sol-gel, co-precipitation, precursor solution technique and hydrothermal process which have been used for the synthesis of ceramics. A systematic flow chart for "wet method" is shown in Figure 2.

Pechini's method: Pechini's method [27] was developed by M.P. Pechini for the synthesis of titanates and niobates for the capacitor industry. The modified Pechini method referred as the citrate gel process or the amorphous citrate gel process has been used for the preparation of a wide variety of ceramic oxide powders. This technique involves mixing of solutions of a metal precursor and an organic poly-functional acid possessing at least one hydroxyl group and one carboxylic acid group such

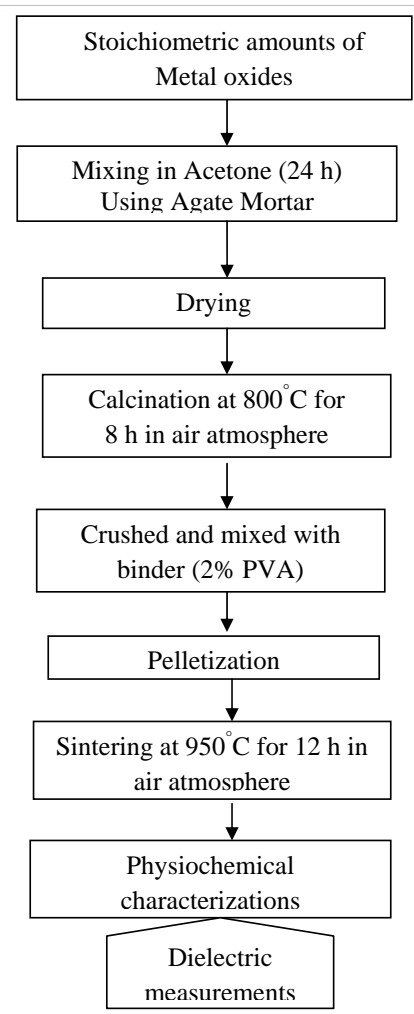

Figure 1: Flow chart for the synthesis of materials by solid state route.

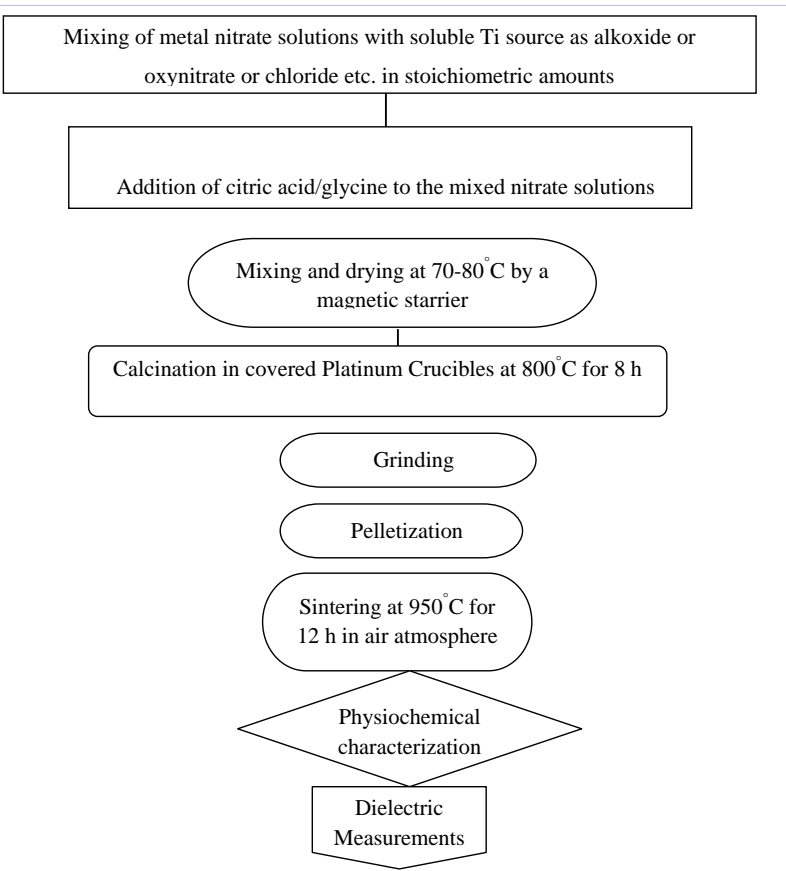

Figure 2: Flow chart for the synthesis of materials by wet method.

as citric acid, glycine, tartaric acid and glycerol, which results in complexation of the metal by the poly-carboxylic acid. The solutions are heated to evaporate water and after its complete removal the highly viscous resin is formed. The resin is then heated to decompose the organic constituents, ground and finally calcined to produce the powder. Pechini route achieves very good chemical homogeneity due to mixing of metal cations on the atomic scale during the polymerization process and this is maintained in the formation of the resin. If none of the constituents volatilizes during the calcination step, the cation composition remains identical to that of the original solution. The disadvantage of the above method is that the material formed from the decomposition of resin is not in the form of a fine powder but consists of charred lumps. These lumps have to be ground and then calcined to produce the final powder. Care should be taken to see that the grinding step may not introduce impurities into the powder. As such the resulting calcination step produces hard agglomerates.

Glycine gel method: Glycine gel nitrate process is one of the types of combustion methods for the synthesis of ceramic powders. A highly viscous mass formed by evaporation of a solution of metal nitrates and glycine is ignited to produce the powder [28]. Glycine is a complexing agent and prevents the precipitation of the metal ions as the water is evaporated. It can form complex with cations at both the carboxylic end and the amino group end as illustrated in Figure 3.

Glycine also serves another important function by providing a fuel for the ignition step of the process as it is oxidized by the nitrate ions. The reactions occurring during ignition are highly explosive and extreme care is required during this step. Normally, only small quantities should be ignited at a time. Under 


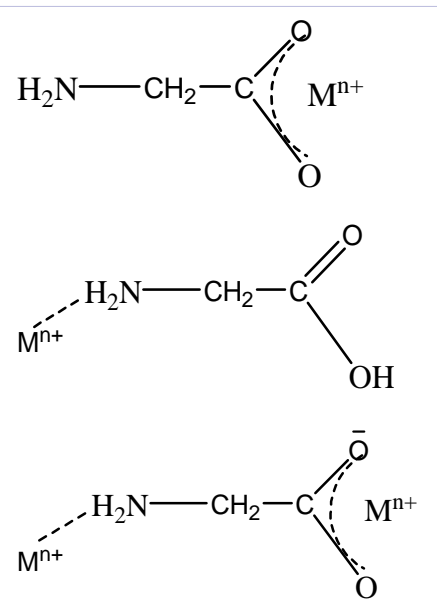

Figure 3: Zwitter-ionic glycine molecule complexing $\mathrm{Mn}^{+}$.

well controlled conditions, a loose mass of very fine crystalline powder is obtained after ignition, so, in contrast to the Pechini method, no grinding is required. The very fine size and crystalline nature of the powder are believed to be direct result of short exposure to high temperature during the ignition step. Glycine gel nitrate process, therefore, offers a relatively/inexpensive route for the synthesis of very fine chemically homogeneous powder. It has been used for the synthesis of simple oxides as well as complex oxides e.g. manganite, chromites, ferrites and oxide superconductors.

Semi wet method: This route is modified sol-gel technique [29]. It is also named as citrate-nitrate gel chemical method which is a type of combustion synthesis technique. Combustion synthesis is generally used to obtain multi-component single phase material. The combustion technique is based on redox reaction between a fuel and oxidant present in the precursor solution. Generally, citric acid, urea, ethylene glycol etc. are used as a fuel and, nitrates of different metals are used as an oxidant. The chelating agents like EDTA, acetic acid etc. can form complex with metal ions present in the precursor solution and act as fuel. This complex, on dehydration, produces a viscous gel which on further heating self-ignites with the evolution of huge amount of gases. This leads to the development of porous floppy ash. Fine phase pure powder can be obtained on further calcinations of the ash at high temperature. In semi-wet route, $\mathrm{TiO}_{2}$ suspension was developed in our laboratory with citric acid solution. All the metal cations were taken as nitrate except $\mathrm{TiO}_{2}$ which was taken as solid. Citric acid was used as the fuel. Flow chart for the synthesis of ССTO and its isomorphs is given in Fig. 4 and a probable complex of metal cations and the citric acid is shown in Fig.5In this route, standard solutions of nitrate of each metal ion were prepared using distilled water. Solutions of metal nitrates in stoichiometric amounts were mixed in a beaker. Stoichiometric amounts of solid $\mathrm{TiO}_{2}$ and aqueous solution of citric acid (equivalent to metal ions) were added to the solution. The solution was then heated on a hot plate with magnetic stirrer at $70-80^{\circ} \mathrm{C}$ to evaporate water. Dehydration of the homogeneously mixed solution during heating caused the development of a gel. This gel on further heating self- ignites followed by its swelling. This ignition product as ash was voluminous and floppy in nature.

\section{Synthesis of CCTO Nano-particles-The Current Status}

\section{Dry methods}

Solid state synthesis is a technique used to produce materials by the reactions carried out at high temperature and pressure. This method is generally used for the mass production of unique, advanced structures for dielectric and piezoelectric. It is a conventional method for preparing ceramics and includes several successive steps of intimate grinding and annealing of the stoichiometric mixture of starting materials.

Solid-state reaction: The solid state synthesis of CCTO powders typically starts with the mixing of precursors by ball milling or other techniques. The most commonly used precursors are $\mathrm{CaCO}_{3}$ (99.9\%), $\mathrm{CuO}(99.9 \%)$ and $\mathrm{TiO}_{2}$ (99.9\%) of high purity chemicals. However, other precursors can also be used in the form of acetate. Generally, the solid state method cannot produce CCTO powders in nanometer scale. However, by modifying this method and parameters it provides the CCTO powders with an average particle diameter of around $500 \mathrm{~nm}$.

Wang et al. [30] synthesized CCTO using nano-size powders containing particle size: $30 \mathrm{~nm}\left(\mathrm{CaCO}_{3}, 99.9 \%\right), 25 \sim 55 \mathrm{~nm}(\mathrm{CuO}$, $99.95 \%)$ and $30 \mathrm{~nm}\left(\mathrm{TiO}_{2}, 99.9 \%\right)$ and foundparticle size in the range $0.1 \sim 0.3 \mu \mathrm{m}$.The samples synthesized with nano-size powders have homogenous microstructure. SEM observation reveals that the particle size of powders calcined with nano powder and micro powder is about $0.5 \sim 1.0 \mu \mathrm{m}$ (a) and $1 \sim$ $2 \mu \mathrm{m}$ (b), respectively. The microstructure of nano-sized derived sample is densified with fine and homogeneous grain distribution, and relative density is $94 \%$, which is higher than that of $91 \%$ derived from micro-meter powder. The CСTO obtained using nano-size raw materials show its dielectric constant by an order more than that produced from submicron particles.

\section{Wet methods}

Wet chemical synthesis routes, such as sol-gel, hydrothermal/ solvothermal, or co-precipitation methods, have more advantages over solid-state reactions in achieving better homogeneity and mixing of the starting compounds on molecular level.

Sol-gel processing: Sol-gel processing is a technique which produces the high purity and homogeneity and lower processing temperatures ceramic powders than traditional ceramic powder methods. Sol-gel processing enables the control of the structure of a material on a nanometer scale from the earliest stages of processing due to mixing in atomic scale. Sols are dispersions of colloidal particles in a liquid. Colloids are solid particles with diameters in the range of 1-100 $\mathrm{nm}$. A gel is an interconnected, rigid network with pores of sub-micrometer dimensions and polymeric chains whose average length is greater than a micrometer. The different precursors, sintering temperature, particle size and dielectric properties have been given in table 1 .

Masingboon et al. [31] fabricated the nano-crystalline $\mathrm{CaCu}_{3} \mathrm{Ti}_{4} \mathrm{O}_{12}$ powders with particle sizes of $50-90 \mathrm{~nm}$ by a simple 
method using $\mathrm{Ca}\left(\mathrm{NO}_{3}\right)_{2} \cdot 4 \mathrm{H}_{2} \mathrm{O}, \mathrm{Cu}\left(\mathrm{NO}_{3}\right)_{2} \cdot 4 \mathrm{H}_{2} \mathrm{O}$, titanium(diisopropoxide) bis(2,4-pentanedionate) and freshly extracted egg white (ovalbumin) in aqueous medium. The average size of the calcined CCTO powders at $700^{\circ} \mathrm{C}$ and $800^{\circ} \mathrm{C}$ were found to be 60 $\mathrm{nm}$ and $100 \mathrm{~nm}$, respectively. Some agglomerates were observed in all of the calcinedpowders. The observed nano-crystalline nature of CCTO by TEM analysis of calcined powder is shown in Figure 6. The electron diffraction of particles $(84.9 \pm 15.3 \mathrm{~nm})$ with higher calcination temperature $\left(800^{\circ} \mathrm{C}\right)$ contains more intense spots (as shown in the Figure 6) than that at $700^{\circ} \mathrm{C}(56.7 \pm 7.9 \mathrm{~nm})$ indicating thereby that the former has size larger than the later.

Thomas et al. [32] developed a wet chemical method for the preparation of complex oxalate precursor, $\mathrm{CaCu}_{3}(\mathrm{TiO})_{4}\left(\mathrm{C}_{2} \mathrm{O}_{4}\right)_{8} \cdot 9 \mathrm{H}_{2} \mathrm{O}(\mathrm{CCT}-\mathrm{OX})$, and the precipitate that obtained was confirmed to be monophasic by the wet chemical analyses, X-ray diffraction, FTIR absorption and TG/DTA analyses. The thermal decomposition of this oxalate precursor led to the formation of phase-pure calcium copper titanate, $\mathrm{CaCu}_{3} \mathrm{Ti}_{4} \mathrm{O}_{12}$, (ССТO) at $680^{\circ} \mathrm{C}$.The precursor gives rise to phase-pure nanoparticles of $\mathrm{CaCu}_{3} \mathrm{Ti}_{4} \mathrm{O}_{12}$ (CCTO) powders with a crystallite size varying from $30-80 \mathrm{~nm}$ when heat treated at $>680^{\circ} \mathrm{C}$; the bright-field TEM micrographs shown in Figure 7 revealed that the sizes of the as synthesized crystallites are in the nanometer range. The ceramic powders so obtained had excellent sinter ability resulting in high density ceramics which exhibited giant dielectric constants up to $40000(1 \mathrm{kHz})$ at $25^{\circ} \mathrm{C}$, accompanied by low dielectric losses, $<0.07$.

Sen et al. [33] developed a novel, low temperature synthetic technique for fabrication of nano-crystalline $\mathrm{CaCu}_{3} \mathrm{Ti}_{4} \mathrm{O}_{12}$ ceramic powders by a metal ion-ligand complex based precursor solution

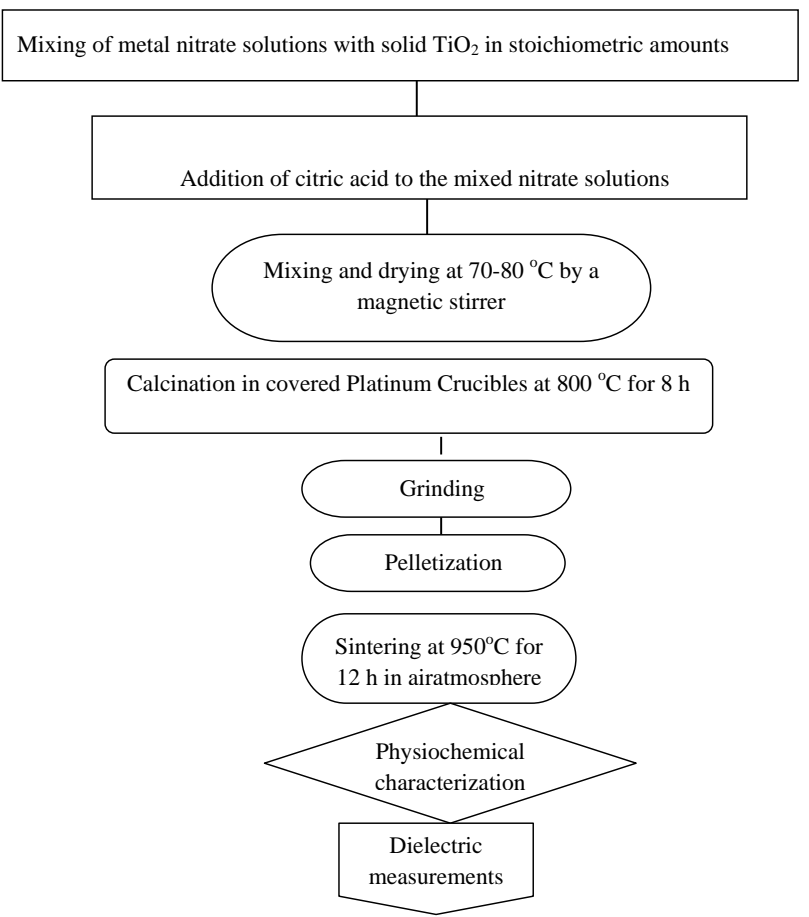

Figure 4: Flow chart for the synthesis of materials by semi-wet route.<smiles></smiles>

Figure 5: A Probable structure of metal-citrate complex.

evaporation method using inexpensive and easily available reagents with high purity raw materials, calcium carbonate $\left(\mathrm{CaCO}_{3}\right)$, copper(II) acetate $\left(\mathrm{Cu}\left(\mathrm{CH}_{3} \mathrm{COO}\right)_{2}\right)$,ethylenediaminet etraacetic acid (EDTA), tri-ethanolamine (TEA) and titanium tartarate.XRD analysis confirmed the formation of cubic phase, with a lattice parameter value of $7.3985^{\circ} \mathrm{A}$. Spherical particles of average $65 \mathrm{~nm}$ size were observed from TEM micrographs after calcination at $700^{\circ} \mathrm{C}$ which was in good agreement with the particle size obtained from the Reitveld analysis.

Banerjee et al. [34] has developed a capillary-enforced template-based method applied to fabricate calcium copper titanate nano-tubes (diameter $200 \mathrm{~nm}$ ) by filling sol-gel CСTO precursor solution into the nano-channels of porous anodic aluminum oxide (AAO) templates and subsequent heating for phase formation and removal of nano-channel templates by applying basic solution. They suggested that this facile method of preparing the $\mathrm{CaCu}_{3} \mathrm{Ti}_{4} \mathrm{O}_{12}$ nano-tubes at a large scale might be important for many applications in nano-devices.XRD and selected-area electron diffraction (SAED) investigations demonstrated that post annealed $\left(750^{\circ} \mathrm{C}\right.$ for $\left.1 \mathrm{~h}\right)$ CCTO nanotubes were polycrystalline with a cubic pseudo-perovskite crystal structure. The FE-SEM and TEM results showed that CCTO nanotubes were of uniform diameter $(\sim 200 \mathrm{~nm})$ throughout their length.

Figure 8 shows TEM image of a CCTO nano-tube after complete removal of AAO template by dissolution in $6 \mathrm{M} \mathrm{NaOH}$ solution. It is clearly seen that nano tube is in hollow structure and enhanced scattering at edges of the tube makes it darker than the middle portion. The diameter of the nano-tube is almost uniform throughout its length which is approximately equal (slightly smaller) to channel diameter of the applied template. Figure 8(b) showed a typical HRTEM image of the wall of a CCTO nano-tube prepared with the help of AAO templates and revealed that the nano-tube is made up of a number of CCTO well-resolved nano-particles that are randomly oriented in the wall. High resolution TEM (HRTEM) analysis confirmed that the obtained CCTO nanotubes are made of randomly aligned nano-particles, 5-10 $\mathrm{nm}$ in size.

Amaral et al. [35] have reported the synthesis and characterization of $\mathrm{CaCu}_{3} \mathrm{Ti}_{4} \mathrm{O}_{12}$ (CCTO) powders prepared by two different wet-chemical methods: ethylene diaminetetraacetic acid-gel method (EDTA)and modified Pechini (MP) process and observed that in both cases, almost single-phase CCTO 
Table 1: Precursors used in the sol-gel synthesis method, metal dopant, particle size, dielctric constant and dielectric loss of the resultant CCTO powders.

\begin{tabular}{|c|c|c|c|c|c|c|c|}
\hline Ca Precursor & Cu Precursor & Ti Precursor & $\begin{array}{l}\text { Dopant tem- } \\
\text { peraturet }\end{array}$ & $\begin{array}{l}\text { Metal } \\
\text { Calcination }\end{array}$ & $\begin{array}{l}\text { Particle } \\
\text { size(nm) }\end{array}$ & $\tan \delta$ & Ref \\
\hline $\mathrm{Ca}\left(\mathrm{NO}_{3}\right)_{2} \cdot 4 \mathrm{H}_{2} \mathrm{O}$ & $\mathrm{Cu}\left(\mathrm{NO}_{3}\right)_{2} \cdot 4 \mathrm{H}_{2} \mathrm{O}$ & titanium(diisopropoxide) & $700^{\circ} \mathrm{C}$ & 60 & $5 \times 10^{4}$ & 0.2 & [31] \\
\hline $\mathrm{CaCO}_{3}$ & $\mathrm{CuCl}_{3}$ & $\mathrm{TiOCl}_{2}$ & $680^{\circ} \mathrm{C}$ & $30-80$ & $4 \times 10^{4}$ & 0.07 & [32] \\
\hline $\mathrm{CaCO}_{3}$ & $\left(\mathrm{Cu}\left(\mathrm{CH}_{3} \mathrm{COO}\right)_{2}\right)$ & titanium tartarate & $700^{\circ} \mathrm{C}$ & 65 & - & - & [33] \\
\hline $\mathrm{Ca}\left(\mathrm{CH}_{3} \mathrm{COO}\right)_{2} \cdot \mathrm{H}_{2} \mathrm{O}$ & $\mathrm{Cu}\left(\mathrm{CH}_{3} \mathrm{COO}\right)_{2} \cdot \mathrm{H}_{2} \mathrm{O}$ & $\left(\mathrm{Ti}-\left\{\mathrm{OCH}\left(\mathrm{CH}_{3}\right)_{2}\right\}_{4}\right)$ & $750^{\circ} \mathrm{C}$ & 200 & - & - & [34] \\
\hline $\mathrm{Ca}\left(\mathrm{NO}_{3}\right)_{2} \cdot 4 \mathrm{H}_{2} \mathrm{O}$ & $\mathrm{Cu}\left(\mathrm{NO}_{3}\right)_{2} \cdot 4 \mathrm{H}_{2} \mathrm{O}$ & $\mathrm{Ti}\left(\mathrm{OC}_{4} \mathrm{H}_{9}\right)_{4}$ & $700{ }^{\circ} \mathrm{C}$ & $50-100$ & $1 \times 10^{4}$ & - & [35] \\
\hline $\mathrm{Ca}\left(\mathrm{NO}_{3}\right)_{2} \cdot 4 \mathrm{H}_{2} \mathrm{O}$ & $\mathrm{Cu}\left(\mathrm{NO}_{3}\right)_{2} \cdot 4 \mathrm{H}_{2} \mathrm{OC}_{12} \mathrm{H}_{28} \mathrm{O}_{4}$ & $\mathrm{Ti}$ & $800^{\circ} \mathrm{C}$ & $60-80$ & $1.06 \times 10^{5}$ & - & [36] \\
\hline $\mathrm{Ca}\left(\mathrm{NO}_{3}\right)_{2} \cdot 4 \mathrm{H}_{2} \mathrm{O}$ & $\mathrm{Cu}\left(\mathrm{NO}_{3}\right)_{2} \cdot 4 \mathrm{H}_{2} \mathrm{O}$ & $\begin{array}{l}\text { titanium isopropyl } \\
\text { orthotitanate }\end{array}$ & $700^{\circ} \mathrm{C}$ & $50-150$ & $5 \times 10^{3}$ & 0.37 & [37] \\
\hline $\mathrm{Ca}\left(\mathrm{NO}_{3}\right)_{2} \cdot 4 \mathrm{H}_{2} \mathrm{O}$ & $\mathrm{Cu}\left(\mathrm{NO}_{3}\right)_{2} \cdot 4 \mathrm{H}_{2} \mathrm{O}$ & $\mathrm{Ti}\left(\mathrm{OC}_{3} \mathrm{H}_{7}\right)_{4}$ & $800^{\circ} \mathrm{C}$ & $90-120$ & $5 \times 10^{4}$ & 6 & [38] \\
\hline $\mathrm{Ca}(\mathrm{Ac})_{2} \cdot \mathrm{H}_{2} \mathrm{O}$ & $\mathrm{Cu}\left(\mathrm{NO}_{3}\right)_{2} \cdot 4 \mathrm{H}_{2} \mathrm{O}$ & tetrabutyltitanate & $750^{\circ} \mathrm{C}$ & $30-80$ & - & - & [39] \\
\hline $\mathrm{Ca}\left(\mathrm{C}_{2} \mathrm{H}_{3} \mathrm{CO}_{2}\right)_{2} \cdot \mathrm{H}_{2} \mathrm{O}$ & $\mathrm{Cu}\left(\mathrm{CH}_{3} \mathrm{COO}\right)_{2} \cdot \mathrm{H}_{2} \mathrm{OC}_{16} \mathrm{H}_{28} \mathrm{O}_{6}$ & $\mathrm{Ti}$ & $800^{\circ} \mathrm{C}$ & $80-200$ & 9516 & 0.02 & [40] \\
\hline $\mathrm{Ca}\left(\mathrm{NO}_{3}\right)_{2} \cdot 4 \mathrm{H}_{2} \mathrm{O}$ & $\mathrm{Cu}\left(\mathrm{NO}_{3}\right)_{2} \cdot 4 \mathrm{H}_{2} \mathrm{O}$ & $\left(\mathrm{Ti}\left(\mathrm{OC}_{3} \mathrm{H}_{7}\right)_{4}\right) \mathrm{Co}$ & $800^{\circ} \mathrm{C}$ & $70-80$ & $2.5 \times 10^{4}$ & - & [41] \\
\hline $\mathrm{Ca}\left(\mathrm{NO}_{3}\right)_{2} \cdot 4 \mathrm{H}_{2} \mathrm{O}$ & $\mathrm{Cu}\left(\mathrm{NO}_{3}\right)_{2} \cdot 4 \mathrm{H}_{2} \mathrm{O}$ & $\mathrm{Ti}\left(\mathrm{OC}_{4} \mathrm{H}_{9}\right)_{4}$ & $800^{\circ} \mathrm{C}$ & 100 & $5.9 \times 10^{4}$ & 0.06 & [42] \\
\hline $\mathrm{Ca}\left(\mathrm{NO}_{3}\right)_{2} \cdot 4 \mathrm{H}_{2} \mathrm{O}$ & $\mathrm{Cu}\left(\mathrm{NO}_{3}\right)_{2} \cdot 4 \mathrm{H}_{2} \mathrm{O}$ & $\left(\mathrm{Ti}\left\{\mathrm{OCH}\left(\mathrm{CH}_{3}\right)_{2}\right\}_{4}\right.$ & $800^{\circ} \mathrm{C}$ & 200 & - & - & [43] \\
\hline $\mathrm{Ca}\left(\mathrm{NO}_{3}\right)_{2} \cdot 4 \mathrm{H}_{2} \mathrm{O}$ & $\mathrm{Cu}\left(\mathrm{NO}_{3}\right)_{2} \cdot 4 \mathrm{H}_{2} \mathrm{O}$ & $\mathrm{Ti}\left(\mathrm{OC}_{3} \mathrm{H}_{7}\right)_{4} \mathrm{Zr}$ & $800^{\circ} \mathrm{C}$ & $47-80$ & $1.27 \times 10^{4}$ & 6 & [44] \\
\hline$\left(\mathrm{Ca}\left(\mathrm{CH}_{3} \mathrm{COO}\right)_{2} \cdot \mathrm{H}_{2} \mathrm{O}\right.$ & $\mathrm{Cu}\left(\mathrm{NO}_{3}\right)_{2} \cdot 4 \mathrm{H}_{2} \mathrm{O}$ & $\mathrm{Ti}\left(\mathrm{OC}_{4} \mathrm{H}_{9}\right)_{4} \mathrm{Zn}$ & $1050^{\circ} \mathrm{C}$ & $2 \mu \mathrm{m}$ & $2.2 \times 10^{4}$ & 0.098 & [45] \\
\hline $\mathrm{Ca}\left(\mathrm{NO}_{3}\right)_{2} \cdot 4 \mathrm{H}_{2} \mathrm{O}$ & $\mathrm{Cu}\left(\mathrm{NO}_{3}\right)_{2} \cdot 4 \mathrm{H}_{2} \mathrm{O}$ & titanium(dilsopropoxide) & $700^{\circ} \mathrm{C}$ & 300 & $>10^{4}$ & 0.05 & [46] \\
\hline $\mathrm{Ca}\left(\mathrm{CH}_{3} \mathrm{COO}\right)_{2} \cdot \mathrm{H}_{2} \mathrm{O}$ & $\mathrm{Cu}\left(\mathrm{NO}_{3}\right)_{2} \cdot 4 \mathrm{H}_{2} \mathrm{O}$ & $\operatorname{Ti}\left(\mathrm{OC}_{4} \mathrm{H}_{9}\right)_{4} \mathrm{Nd}$ & $800^{\circ} \mathrm{C}$ & $120-250$ & $1.12 \times 10^{4}$ & 0.12 & [47] \\
\hline
\end{tabular}
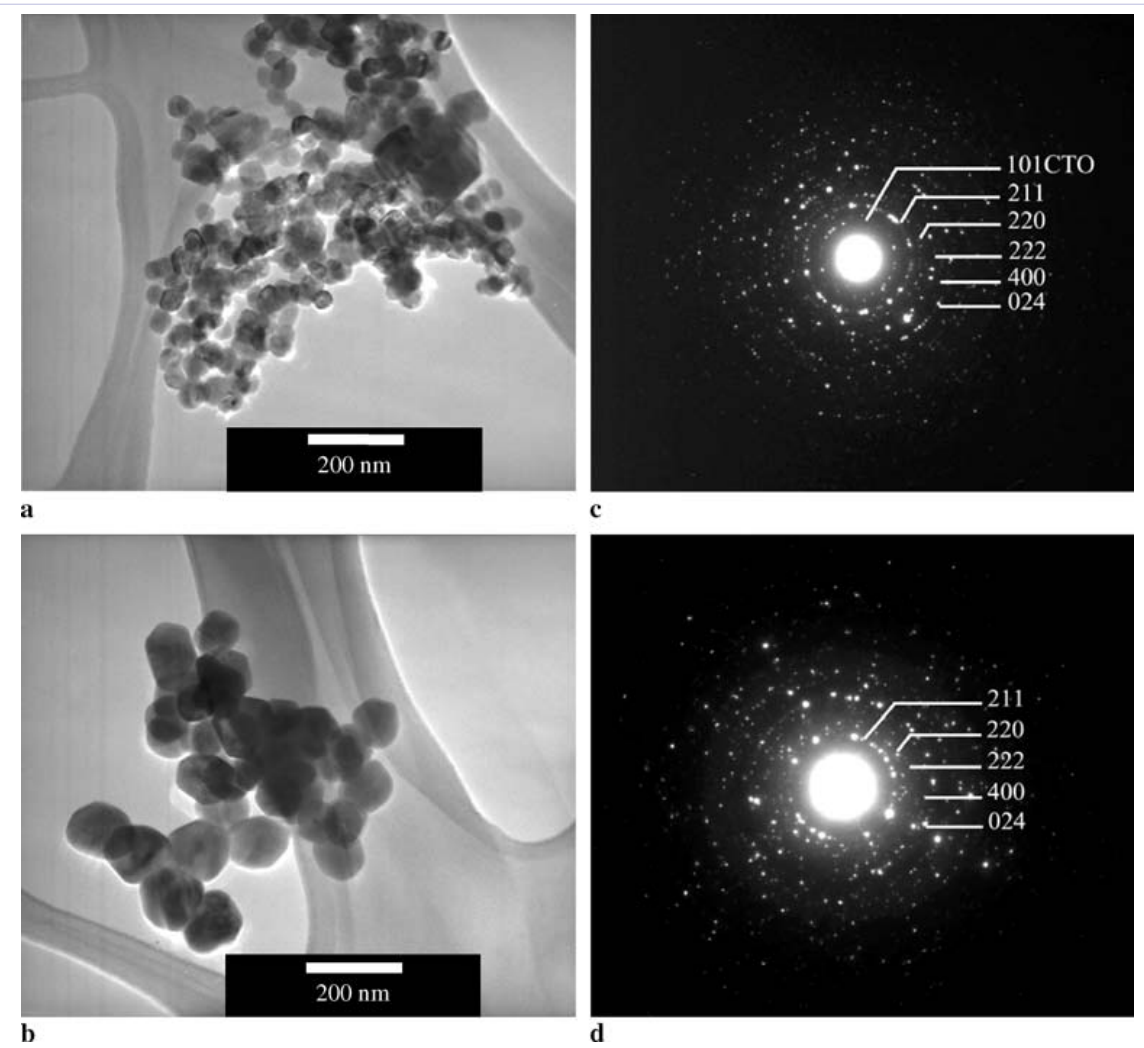

Figure 6: Bright field TEM images with corresponding selected area electron diffraction (SAED) pattern of $\mathrm{CaCu}_{3} \mathrm{Ti}_{4} \mathrm{O}_{12}$ powders calcined in air for 8 $\mathrm{h}$ at different temperatures: (a) $700^{\circ} \mathrm{C}$ and (b) $800^{\circ} \mathrm{C}[31]$. 


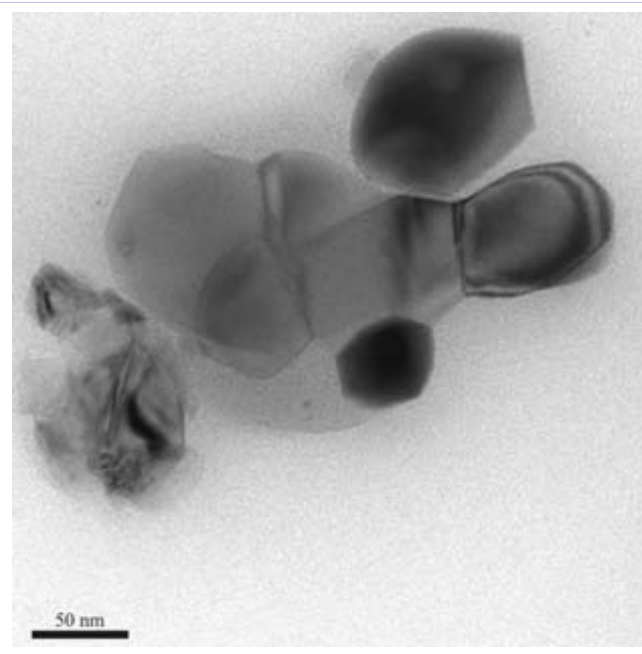

Figure 7: Bright field TEM image of CCTO with particle dimensions ranging from $30-80 \mathrm{~nm}[32]$.
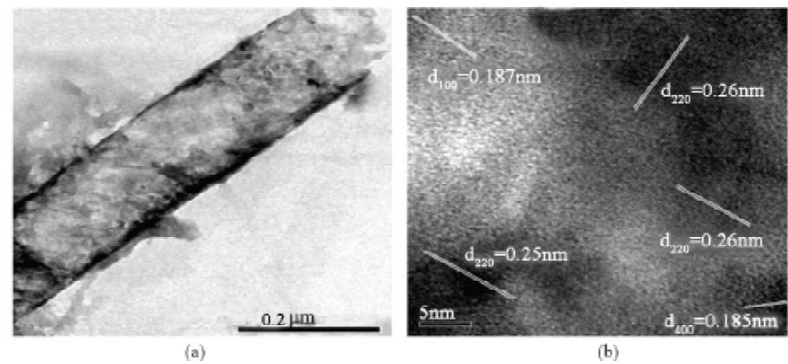

Figure 8: TEM image of (a) CCTOnano-tube after complete removal of AAO template; (b) Singlenano-tube surface revealing that it is comprised of a number of randomly oriented particles [34].

fine powders were obtained from the calcination of the gel precursors at lower temperatures and shorter times than those reported for the conventional solid state reaction process. The SEM image of the powder calcined at $700{ }^{\circ} \mathrm{C}$ and prepared by the MP method present nano-size particles in spherical form with size ranging between 50 and $100 \mathrm{~nm}$. The grain size of sintered pellets produced from the powders obtained by the MP process present larger mean grain size compared to the pellets obtained from EDTA-gel method. This fact agrees well with IBLC model, and a higher dielectric permittivity was predicted for the samples produced by MP process than that by the EDTA method.

C. Kumar et al. [36] prepared the calcium copper titanate (CСTO) nano-powder by the sol-gel self- combustion method. The X-ray diffraction analysis indicated that the samples calcined at $800^{\circ} \mathrm{C}$ were fully crystallized in the CCTO phase. The atomic force microscopic studies showed that their particle size was in the range of 60-80 nmas given in Figure 9.

The absorption bands corresponding to vibrations of $\mathrm{Cu}-\mathrm{O}$, Ti-O-Ti and $\mathrm{m} \mathrm{Ca-O}$ were observed at 512, 450 and $562 \mathrm{~cm}^{-1}$ using FTIR. The CCTO pellets were sintered at low temperature of $950^{\circ} \mathrm{C}$. A large value of dielectric constant, in the order of $10^{6}$, was due to the low sintering temperature and uniform microstructure.
Kumar et al. [37] synthesized the nano-particles of $\mathrm{CaCu}-$ ${ }_{3} \mathrm{Ti}_{4} \mathrm{O}_{12}$ by sol-gel reaction route sintered at $1025^{\circ} \mathrm{C}$ with reduced sintering time and obtained CCTO samples with high dielectric constant $\varepsilon \sim 5000$ and $\tan \delta \sim 0.37$ at $10 \mathrm{~Hz}$. The TEM images of the as calcined powder at $700^{\circ} \mathrm{C}$ show large agglomerates of nano-particles in Figure 10. The average particle size was in the $50-150 \mathrm{~nm}$ range. The agglomeration may be due to strong interparticle forces between the particles.

Jesurani et al. [38] prepared the precursor of $\mathrm{CaCu}_{3} \mathrm{Ti}_{4} \mathrm{O}_{12}$ (CCTO) nano-particles by sol-gel method at $90^{\circ} \mathrm{C}$. The dried precursor powder was milled and then calcined at $450^{\circ} \mathrm{C}, 550^{\circ} \mathrm{C}, 650^{\circ} \mathrm{C}, 800^{\circ} \mathrm{C}, 850^{\circ} \mathrm{C}$ and $950^{\circ} \mathrm{C}$ for $3 \mathrm{~h}$. The single

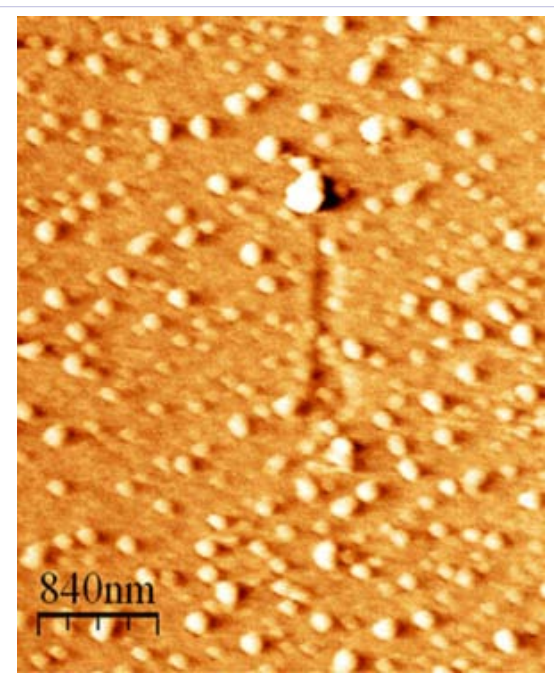

Figure 9: AFM image of CCTO Nano-powder calcined at $800^{\circ} \mathrm{C}[36]$.

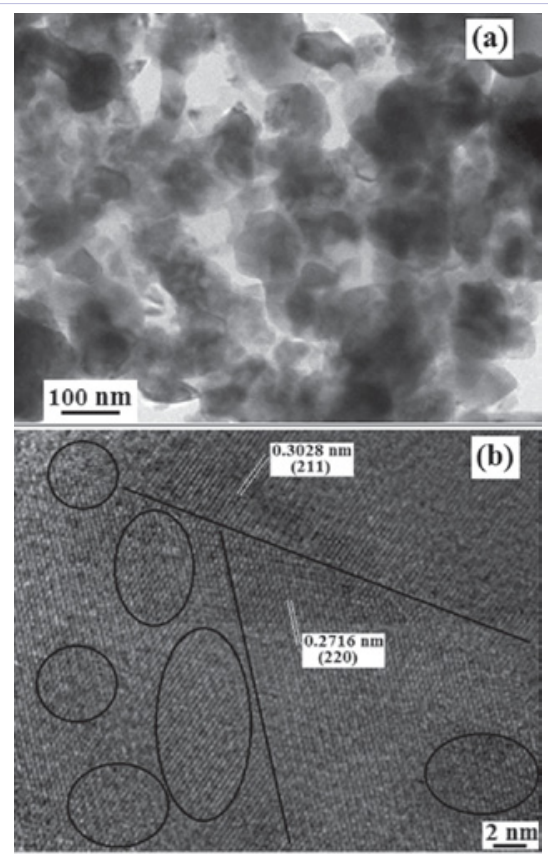

Figure 10: AFM image of CCTO Nano-powder calcined at $800^{\circ} \mathrm{C}[36]$. 
phase formation of CCTO was analyzed by step by step using FTIR and XRD. The absorption bands corresponding to vibrations of Ca-O, Cu-O and Ti-O-Ti were observed at 606, 525 and $463 \mathrm{~cm}^{-1}$ using FTIR. The particle size from AFM is about $90-120 \mathrm{~nm}$. The grain size varies from $500 \mathrm{~nm}$ to $6 \mu \mathrm{m}$ as measured by FE-SEM. The FE-SEM micrographs clearly show bi-modal distribution of grains; the smaller grains have size range from $500 \mathrm{~nm}$ to $2 \mu \mathrm{m}$ and the larger grains have size rangefrom 2 to $6 \mu \mathrm{m}$. The bimodal distributions of grains indicate that the sol-gel derived CCTO powders have hard agglomerates which on sintering form large grains. The CCTO pellets were sintered at low temperature of $1040^{\circ} \mathrm{C}$. A giant value of dielectric constant, of the order of $10^{5}$, was measured due to the low sintering temperature and dense microstructure.

Tian et al. [39] prepared $\mathrm{CaCu}_{3} \mathrm{Ti}_{4} \mathrm{O}_{12}$ nano-powders by a solgel route with calcinations temperature $750^{\circ} \mathrm{C}$, using tetra-butyltitanate, calcium acetate and cupric nitrate as precursors. The xero-gel and the formation of single-phase CCTO with different calcining temperatures at $350^{\circ} \mathrm{C}, 550^{\circ} \mathrm{C}$, and $750^{\circ} \mathrm{C}$ in air were confirmed by the FTIR analysis. When precursor powder was treated at $750^{\circ} \mathrm{C}$ for $3 \mathrm{~h}$, the obtained sample shows pure CСTO XRD peaks indicating its high crystallization and good purity and the average size of the crystalline particles were calculated to be $50.3 \mathrm{~nm}$ based on the Debye-Scherrer formula. TEM image of the CCTO at $750^{\circ} \mathrm{C}$ showed that the size of nano-crystals is in the range $30-80 \mathrm{~nm}$, which is roughly close to the size obtained from the "Debye-Scherrer" formula. The obtained $\mathrm{CaCu}_{3} \mathrm{Ti}_{4} \mathrm{O}_{12}$ nanopowders were investigated as a gassensitive material responding to ethanol atmosphere, and it showed high sensitivity for ethanol gas. Their studies, not only enrich the contents of CCTO chemistry, but are also beneficial to investigate their potential application in gas sensors.

Vangchangyia et al. [40] prepared CCTO ceramics using Caand $\mathrm{Cu}$-acetates as starting raw materials by a modified sol-gel method with different calcining conditions and showed excellent dielectric properties. The precursor was ground and calcined in air at $850^{\circ} \mathrm{C}$ for $2 \mathrm{~h}$ (ССTO-1), $850^{\circ} \mathrm{C}$ for $8 \mathrm{~h}$ (CСTO-2), and $900^{\circ} \mathrm{C}$ for $4 \mathrm{~h}$ (ССТО-3) and was finally sintered in air at $1100^{\circ} \mathrm{C}$ for 6h.Themicrostructure of CCTO ceramics are shown in Figure 11(a-d).The presence of impurity phases in calcined powder at $850^{\circ} \mathrm{C}$ for $2 \mathrm{~h}$ has a significant influence on the microstructure of sintered ССТО-1 ceramic. The microstructure of the ССТО1 ceramic shows a large amount of pores; CCTO-2 and CCTO-3 ceramics are relatively dense. Figure 11 (d) shows a TEM image of CCTO-3 particles, revealing a large distribution of particle sizes $\sim 80-200 \mathrm{~nm}$. At $1 \mathrm{kHz}$ and at room temperature, the best ССТO ceramic can exhibit a high dielectric constant $\left(\varepsilon_{\mathrm{r}}\right)$ of 9516 with a very low dielectric loss, $\tan \delta \sim 0.020$. The minimum value of $\tan \delta$ is 0.018 at $2.5 \mathrm{kHz}$ with $\varepsilon_{\mathrm{r}} \sim 9433$.

Jesurani et al. [41] successfully prepared the $\mathrm{CaCu}_{3} \mathrm{Ti}_{(4-\mathrm{x})}$ $\mathrm{Co}_{\mathrm{x}} \mathrm{O}_{12}$ (CCTCO, $0 \leq \mathrm{x} \leq 1.0$ ) ceramics by sol-gel method. XRD analysis indicated that the ceramics consisted of a single phase, without structural change in CCTO. HRSEM image in Figure 12 of $\mathrm{CaCu}_{3} \mathrm{Ti}_{(4-\mathrm{x})} \mathrm{Co}_{\mathrm{x}} \mathrm{O}_{12}$ where $\mathrm{x}=0,0.02,0.1,0.2,0.5$ and 1.0, showed that some CCTCO grains are distinguishable in lower

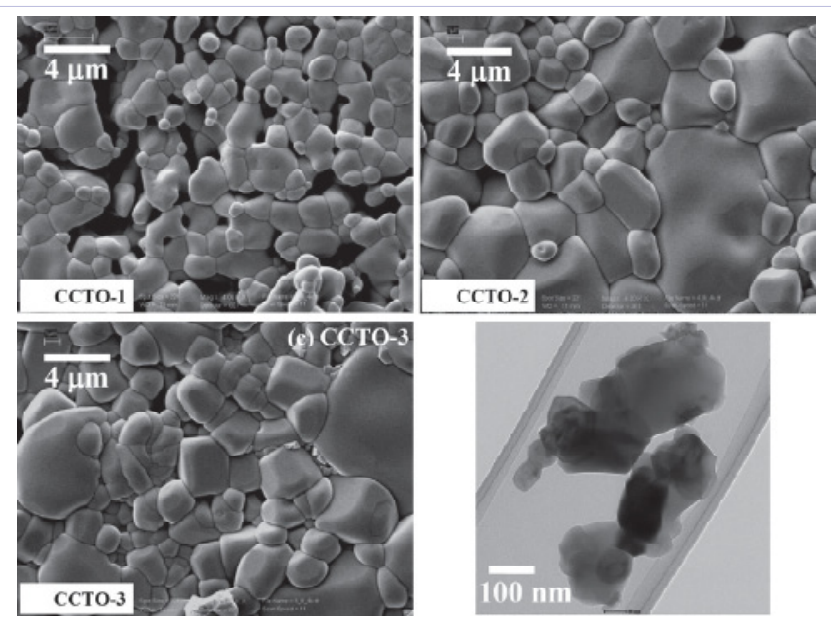

Figure 11: SEM images (a) CCTO-1, (b) CCTO-2, (c) CCTO-3 ceramic samples, and (d) TEM image of CCTO-3 powder [40].

concentration and appear to be highly agglomerate in higher doping concentration and enhanced the grain growth.

The grains were found to be regular and polyhedral type in the lower concentration of Co dopant. The un-doped specimen consists of some huge grains, surrounded by small ones. The dielectric study showed that the dielectric constant reached a value as high as $\left(\varepsilon_{\mathrm{r}}=25,400\right.$ at 1,000 and $\varepsilon_{\mathrm{r}}=111,000$ at $\left.1,050{ }^{\circ} \mathrm{C}\right)$ at a cobalt-doping concentration of $\mathrm{x}=0.2$ at low frequency ( 50 $\mathrm{Hz}$ ) whereas the $\varepsilon_{\mathrm{r}}$ valuesof the samples with $\mathrm{x}=0.00,0.02,0.1$ and 1.0 remainal most unchanged with good frequency stability at higher frequency and they are much smaller than those of the CCTCO (where $\mathrm{x}=0.2$ and 0.5 ).

Zhao et al. [42] synthesized CCTO nano-size powders by solgel route using analytical grade $\mathrm{Ca}\left(\mathrm{NO}_{3}\right)_{2} 4 \mathrm{H}_{2} \mathrm{O}, \mathrm{Cu}\left(\mathrm{NO}_{3}\right)_{2} 3 \mathrm{H}_{2} \mathrm{O}$ and $\mathrm{Ti}\left(\mathrm{OC}_{4} \mathrm{H}_{9}\right)_{4}$ were used as the starting materials. The thermal decomposition process, phase structures and morphology of synthesized powders were studied by IR, DSC-TG, XRD, TEM and FT-IR spectrum of CCTO. Dry precursors showed that a strong and broad absorption band in the region of 2800-3600 $\mathrm{cm}^{-1}$, centered at $3447 \mathrm{~cm}^{-1}$, originated from the $\mathrm{O}-\mathrm{H}$ vibration of weak-bound water, butanol and $\mathrm{C}-\mathrm{H}$ vibration of alkyl groups. The characteristic absorption peaks of $\mathrm{NO}_{3}{ }^{2}$ appear near the wave number $1382 \mathrm{~cm}^{-1}$. The absorption peaks of $1636 \mathrm{~cm}^{-1}$, $1543 \mathrm{~cm}^{-1}$ and $1045 \mathrm{~cm}^{-1}$ are attributed to the asymmetrical stretching vibration and the symmetrical stretching vibration of -COO-The investigation of DSC/TG showed that the main weightloss and decomposition of precursors occurred below $450^{\circ} \mathrm{C}$ and CCTO crystallite gradually appeared and became stronger when the calcination temperature was higher than $700^{\circ} \mathrm{C}$. CCTO-based ceramics with excellent dielectric properties $\left(\varepsilon_{25}=5.9 \times 10^{4}\right.$, tan $\delta=0.06$ at $1.0 \mathrm{kHz}$ ) were prepared by sintering at $1125^{\circ} \mathrm{C}$, and proposed that a conduction mechanism was responsible for the origin of giant dielectric constant in CСTO system.

Banerjee et al. [43] reported the low-dimensional fabrication of technologically important patterned nano-dots of giant dielectric material $\mathrm{CaCu}_{3} \mathrm{Ti}_{4} \mathrm{O}_{12}$ (CCTO) on platinized silicon substrate 
with defined size, shape and separation using soft electron beam lithographic technique. The fabrication procedure is typically constituted of two steps. In the first step nano-fabrication was prepared on substrate surface by e-beam lithographic process. Next the sol-gel precursor solution of the CCTO made up using inorganic metal nitrates and Ti-iso-propoxide were spun-coated onto it which subsequently followed by drying, lift-off and annealing to yield nano-fabricated dense ceramic material. Phase purity and crystallinity of post-annealed dots were confirmed by X-ray diffraction studies. Morphology of the dots was investigated with atomic force microscopy where it was found that they have an average diameter of $200 \mathrm{~nm}$ with average height of 50 $\mathrm{nm}$. TEM and EDX analysis of an isolated CCTO nano-dot is presented in Figure 13.

The size of the nano-structure is found to match well to that obtained from SEM studies. Some over growth can also be seen in the image. Corresponding selected area electron diffraction (SAED) pattern is given in Figure 13(b) which reveals the polycrystalline nature and the rings in the SEAD pattern corresponds to (422), (400), (013), (220) and (200) crystal planes of cubic pseudo-perovskite phase of CCTO. The EDX spectrum in Figure 13(c) confirmed the characteristics of all elements present in CCTO ceramic.

Jesurani et al. [44] successfully prepared the giant dielectric constant $\mathrm{Zr}$ substituted $\mathrm{CaCu}_{3} \mathrm{Ti}_{4-\mathrm{x}} \mathrm{Zr}_{\mathrm{x}} \mathrm{O}_{12}$ (CCTZO) with $\mathrm{x}=0.00$, $0.02,0.10,0.20$ and $0.50 \mathrm{~mol} \%$ nano powder by sol-gel technique with lower processing temperaturefrom the metal nitrate solutions, titanium isoproxide and zirconium oxy chloride. XRD analysis confirmed the formation of a single phase material in the ceramics calcinated at $800^{\circ} \mathrm{C}$ for $3 \mathrm{~h}$. The crystal structure did not change on doping with zirconium and it remained cubic in all compositions. AFM studies in Figure 14 showed that the particle size of the CCTZO powder ranged from 47 to $85 \mathrm{~nm}$ and shapes of the particles were polyhedral in nature.

FE-SEM micrographs of the $\mathrm{CaCu}_{3} \mathrm{Ti}_{4-\mathrm{x}} \mathrm{Zr}_{\mathrm{x}} \mathrm{O}_{12}$ ceramics showed that the grain size was in the range of $250 \mathrm{~nm}$ to 5 $\mu \mathrm{m}$ for these samples. When $\mathrm{Zr}$ concentration increases, the size of the in-boundary particles were found to be change. Increasing zirconium concentration on CCTO resulted in dense microstructure of the sample, which could possess excellent

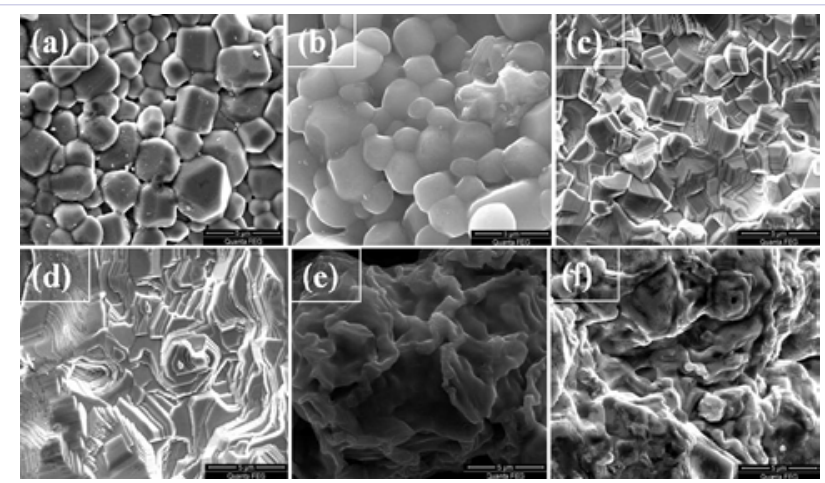

Figure 12: HRSEM microstructures of $\mathrm{CaCu}_{3} \mathrm{Ti}_{(4-x)} \mathrm{Co}_{x} \mathrm{O}_{12}[\mathrm{x}=0,0.02,0.1$, $0.2,0.5$ and 1.0$]$ respectively [41].

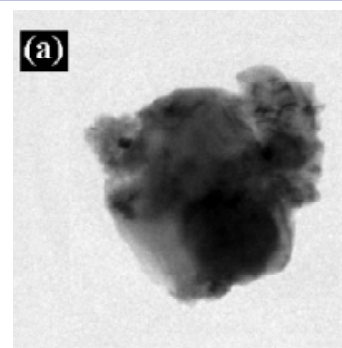

$\underline{100 \mathrm{~nm}}$

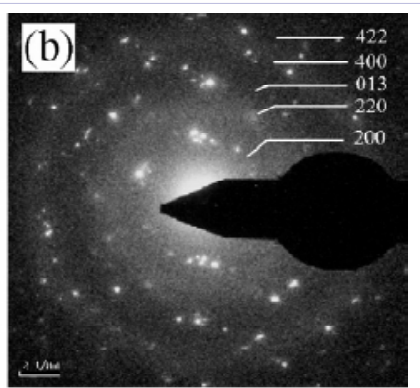

$\mathrm{Cu}$

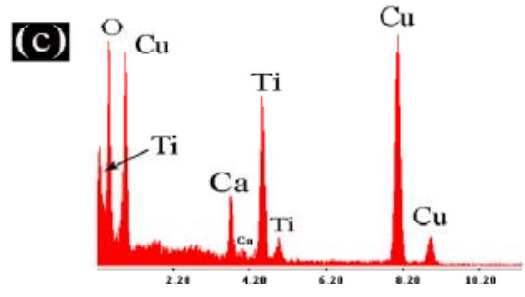

Figure 13: (a) TEM image of an isolated $\mathrm{CaCu}_{3} \mathrm{Ti}_{4} \mathrm{O}_{12}$ nano-dot. (b) SAED pattern of nano-dots (c) Corresponding energy dispersive X-ray analysis (EDX) spectrum [43].
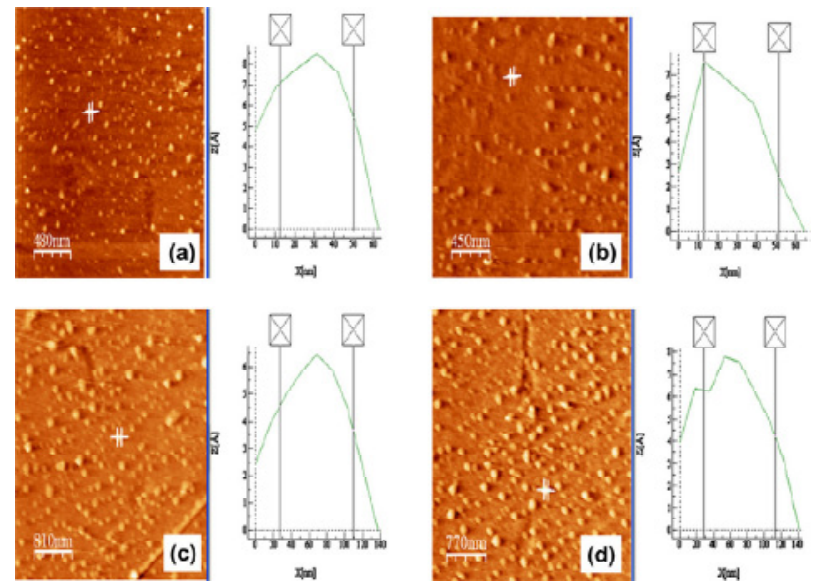

$x \times 1$

Figure 14: AFM measurement of nano-powderscalcined at $800^{\circ} \mathrm{C}$ for $3 \mathrm{~h}$ $\mathrm{CaCu}_{3} \mathrm{Ti}_{4-} \mathrm{Zr}_{\mathrm{x}} \mathrm{O}_{12}(\mathrm{x}=0.02,0.10,0.20$ and $0.50 \mathrm{~mol} \%)$ [44].

electrical properties. Formation of barrier layers and presence of interfacial polarization gave rise to increased value of the dielectric constant. The effect of doping $\mathrm{Zr}[\mathrm{x}=0.02,0.1,0.2$ and $0.5 \mathrm{~mol} \%]$ on the dielectric constants of samples sintered at $1020^{\circ} \mathrm{C}$ and $1040^{\circ} \mathrm{C}$ are shown in Figure 15 (a\& b).

The high dielectric constants of these samples are 2960, 4190,4610 and 6770 and the corresponding dielectric losses are $0.5,1.0,1.0$ and 1.0. The results show that the highest dielectric constant at $50 \mathrm{~Hz}$ is achieved when the dopant concentration is 0.5 . In the case of ceramic sintered at $1040^{\circ} \mathrm{C}$ it may be observed that the highest dielectric constant is obtained when the concentration value of $\mathrm{x}$ is 0.1 . According to these results zirconium with $\mathrm{x}=0.1$ gives high dielectric constant 12,700 and low dielectric loss of 3.0.

$\mathrm{Xu}$ et al. [45] prepared Zn-substituted $\mathrm{CaCu}_{3} \mathrm{Ti}_{4} \mathrm{O}_{12}$ ceramics by the sol-gel method using the precursors of $\mathrm{Ca}\left(\mathrm{CH}_{3} \mathrm{COO}\right)_{2} \cdot \mathrm{H}_{2} \mathrm{O}$, 

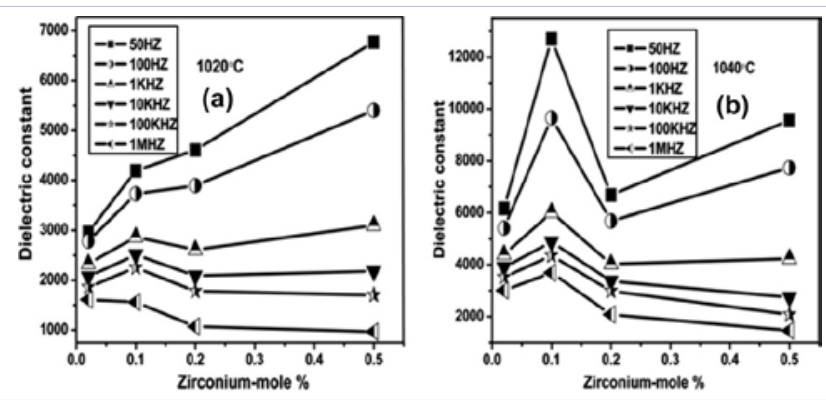

Figure 15: Effects of zirconium doped $\mathrm{CaCu}_{3} \mathrm{Ti}_{4} \mathrm{O}_{12}$ ceramics on the dielectric constant sintered at 1020 and $1040^{\circ} \mathrm{C}$ [44].

$\mathrm{Cu}\left(\mathrm{NO}_{3}\right)_{2} \cdot 3 \mathrm{H}_{2} \mathrm{O}, \mathrm{Zn}\left(\mathrm{CH}_{3} \mathrm{COO}\right)_{2} \cdot 2 \mathrm{H}_{2} \mathrm{O}$ and $\mathrm{Ti}\left(\mathrm{OC}_{4} \mathrm{H}_{9}\right)_{4} \cdot \mathrm{XRD}$ analysis indicated that $\mathrm{CaCu}_{3-\mathrm{x}} \mathrm{Zn}_{\mathrm{x}} \mathrm{Ti}_{4} \mathrm{O}_{12}$ (CCZTO) ( $\mathrm{x}=0.00,0.06,0.10$, 0.20 ) ceramics, after sintering at $1050^{\circ} \mathrm{C}$ for $20 \mathrm{~h}$, consisted of a single phase, with no secondary phases.SEM results indicated that the samples had smaller grain sizes than those synthesized by traditional solid-state reaction methods and also found that some $\mathrm{ZnO}$ grains appeared on the grain boundaries in $\mathrm{CaCu}_{2.9} \mathrm{Zn}_{0.1} \mathrm{Ti}_{4} \mathrm{O}_{12}$ and $\mathrm{CaCu}_{2.8} \mathrm{Zn}_{0.2} \mathrm{Ti}_{4} \mathrm{O}_{12}$, which led to grain confinement in the CCTO. From the dielectric measurements it was found that $\mathrm{CaCu}_{2.94} \mathrm{Zn}_{0.06} \mathrm{Ti}_{4} \mathrm{O}_{12}$ (the sample with $\mathrm{x}=0.06$ ) had the best properties, with the highest nonlinear coefficient, the lowest threshold field, a high dielectric constant and a low dielectric loss factor at frequencies below $10^{5} \mathrm{~Hz}$. These properties make it a candidate for applications in low voltage varistor switchings, gassensing devices and varistor-capacitor double property devices.

Banerjee et al. [46] has prepared the giant dielectric material $\mathrm{CaCu}_{3} \mathrm{Ti}_{4} \mathrm{O}_{12}$ (CCTO) through a simple, cost-effective, environment friendly and energetically beneficial pathway involving solutioncombustion of an aqueous precursor solution. The metal-ion precursors are mainly inorganic salts of corresponding metals except Ti-isopropoxide which was hydrolyzed and converted in situ to water soluble Ti-oxynitrate by application of nitric acid. On combustion with urea as the external fuel the precursor solution generated precursor fluffy mass which on calcination produced pure CCTO phase at as low temperature as $700^{\circ} \mathrm{C}$. The pathway yields phase-pure and impurity-less CCTO ceramic at an ultra-low temperature $\left(700^{\circ} \mathrm{C}\right)$ and is better than those obtained by the traditional solid-state reaction. From the X-ray diffractogramsit is evident that the powder calcinated at $700^{\circ} \mathrm{C}$ has the proper $\mathrm{CaCu}_{3} \mathrm{Ti}_{4} \mathrm{O}_{12}$ phase. On microscopic investigation, the matrix using SEM and TEM were seemed to be nano-crystalline and highly porous with pore sizes in the range of $\sim 0.1-1.5 \mu \mathrm{m}$. The porous ceramic matrix on grinding produced CCTO powder having particle size in submicron order with an average size $300 \mathrm{~nm}$. On sintering at $1050^{\circ} \mathrm{C}$ for $5 \mathrm{~h}$ the powder shows high dielectric constants $\left(>10^{4}\right.$ at all frequencies from $100 \mathrm{~Hz}$ to 100 $\mathrm{kHz}$ ) and low loss (with 0.05 as the lowest value) which is suitable for device applications.

Wang et al. [47] employed the sol-gel method to synthesize pure and $\mathrm{Nd}$ doped $\mathrm{Ca}_{(1-3 \mathrm{x} / 2)} \mathrm{Nd}_{\mathrm{x}} \mathrm{Cu}_{3} \mathrm{Ti}_{4} \mathrm{O}_{12}(\mathrm{x}=0,0.1,0.2$ and 0.3$)$ ceramics.XRD patterns show that CNCTO ceramics (sintered at $1,000^{\circ} \mathrm{C}$ for $6 \mathrm{~h}$ ) were single phase with no $\mathrm{Cu}$-rich phase. The lattice parameters show an increasing trend with the enhancing amount of $\mathrm{Nd}^{3+}$ substitution. SEM picture in Figure 16 reveals that particlesize monotonously decreases from 250 to $120 \mathrm{~nm}$ withincrease of $\mathrm{Nd}$ concentration. The average grain size of CCTO ceramics decrease from 2.0 to $0.8 \mu \mathrm{m}$ with increase in $\mathrm{Nd}$ doping, which indicates that high concentration of $\mathrm{Nd}$ inhibits grain growth of $\mathrm{CaCu}_{3} \mathrm{Ti}_{4} \mathrm{O}_{12}$. Both the dielectric constant anddielectric loss decrease with increase in $\mathrm{Nd}$ concentrations. $\mathrm{Ca}_{(1-3 \mathrm{x} / 2)}$ $\mathrm{Nd}_{\mathrm{x}} \mathrm{Cu}_{3} \mathrm{Ti}_{4} \mathrm{O}_{12}$ ceramics with $\mathrm{x}=0.3$ shows thelowest dielectric constant of $1.12 \times 10^{4}$ as well as the lowest dielectric loss value of 0.12 at $20^{\circ} \mathrm{C}(10 \mathrm{kHz})$.This is due to high concentration of $\mathrm{Nd}$ concentration on planar defects in ССTO which could increase the electrical resistivity of the internal barrier and decrease the dielectric loss.

Sang wong et al. [48] successfully synthesized the nanocrystalline $\mathrm{CaCu}_{3} \mathrm{Ti}_{4} \mathrm{O}_{12}$ powders by a polyvinyl pyrrolidonedimethyl-formamide (PVP-DMF) solution route. XRD showed that pure phase of CCTO was achieved at a low calcination temperature and short reaction time at $800^{\circ} \mathrm{C}$ for $3 \mathrm{~h}$.TEM images of powders calcined at 700 and $750^{\circ} \mathrm{C}$ for $3 \mathrm{~h}$ with crystallite size of about $100 \mathrm{~nm}$. The crystalline particles with necking growth of grains are clearly observed in this sample with the crystallite size in the range of $\sim 200-500 \mathrm{~nm}$. The sintered CСTO ceramics exhibited very high dielectric constants of about 12,590 and37,685 for the ceramics sintered at $1050^{\circ} \mathrm{C}$ for 3 and $12 \mathrm{~h}$, respectively. The nonlinear current-voltage behavior is closely related to the microstructure of CСТО ceramics.

Spray pyrolysis: Another solution-based approach in the synthesis of $\mathrm{ABO}_{3}$ perovskite type $\mathrm{CaCu}_{3} \mathrm{Ti}_{4} \mathrm{O}_{12}$ and its isomorphs is spray pyrolysis which is an effective technique for obtaining the CCTO powders with fine size and regular morphology. The starting solutions can be sprayed ultrasonically or peristaltically into the high-temperature reactor by a carrier gas. The precursor solution can be made by dissolving stoichiometric amounts of calcium nitrate, copper nitrate and water soluble Ti-oxynitrate.
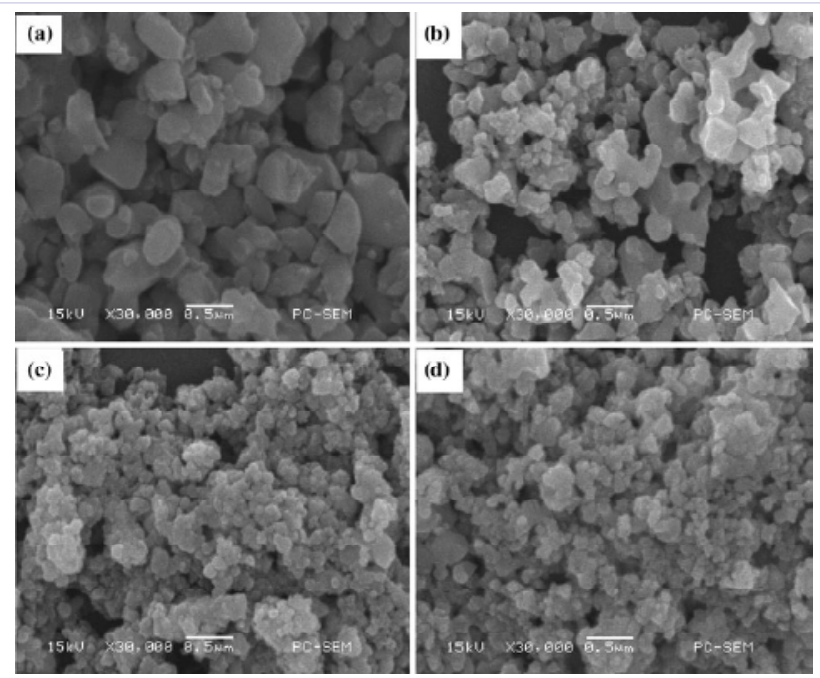

Figure 16: SEM images of (a) CCTO(b) CNCTO $\mathrm{x}=0.10$ (c) CNCTO $\mathrm{x}=0.20$ (d) CNCTO $\mathrm{x}=0.30$ [47]. 
Liu et al. [49] synthesized CCTO by pyrolyzing an organic solution containing stoichiometric amounts of the metal cations in a stable solution prepared by dissolving calcium nitrate, copper(II) nitrate, and titanium(IV) isopropoxide in 2-methoxyethanol. This solution was pyrolyzed and heattreated to achieve single-phase CCTO, which is done at lower temperature and shorter reaction time than the conventional solid-state reaction. The X-ray diffraction analysis showed that the sample heated at $700^{\circ} \mathrm{C}$ for $2 \mathrm{~h}$ produced the CCTO at a much lower reaction temperature and shorter time than those required for the solid-state reaction, i.e., $1000^{\circ} \mathrm{C}$ for $20 \mathrm{~h}$.The SEM analysis shows grain dimensions in the $200-400 \mathrm{~nm}$ range which increase to 2-3 $\mu \mathrm{m}$ after being cold-pressed into pellets and sintered at $1050{ }^{\circ} \mathrm{C}$ for $4 \mathrm{~h}$. The dielectric behavior of the sintered sample is similar to that of ССТО made by solid-state reaction with its dielectric constant 11500 independent of frequency and temperature below the relaxation frequency.

Liu et al. [50] have also synthesized CCTO using two wetchemistry methods, namely, combustion method and the pyrolysis method at relatively low temperature and short heat treatment duration using $\mathrm{Ca}\left(\mathrm{NO}_{3}\right)_{2} \cdot 4 \mathrm{H}_{2} \mathrm{O}, \mathrm{Cu}\left(\mathrm{NO}_{3}\right)_{2} \cdot 2.5 \mathrm{H}_{2} \mathrm{O},\left(\mathrm{Ti}\left[\mathrm{OCH}\left(\mathrm{CH}_{3}\right)_{2}\right]_{4^{\prime}}\right.$ anhydrous citric acid, acetylacetone, 2,4-pentanedione and anhydrous ethylene glycol. In both methods, the metal oxides are formed in the first heat treatment step and CCTO is produced by a subsequent solid state reaction. X-ray diffraction analysis shows that the sample prepared by combustion method treated at $800{ }^{\circ} \mathrm{C}$ for $2 \mathrm{~h}$, has pure CСTO, with no detectable impurities and sample synthesized by pyrolysis method produced the ССTO pure phase at $800{ }^{\circ} \mathrm{C}$ for $1 \mathrm{~h}$ without any secondary phase. Scanning electron microscopy (SEM) of thecombustion method sample after sintering for $4 \mathrm{~h}$ at $1030{ }^{\circ} \mathrm{C}$, showed that the grain sizes have a narrow distribution in the range of $0.4-1.0 \mu \mathrm{m}$. The sample produced by pyrolysis method and sintered at $1030{ }^{\circ} \mathrm{C}$, has particle dimensions in the range of $0.5-1.5 \mu \mathrm{m}$, which is a little larger than those obtained by the combustion method while dielectric behaviors of both samples are similar. Specifically, they all have a Debye-like relaxation with a steep decrease in $\varepsilon^{\prime}$ at the frequency where $\varepsilon^{\prime \prime}$ displays a relaxation peak. At -150 ${ }^{\circ} \mathrm{C}$ and $113.38 \mathrm{~Hz}$, the measured dielectric constant of sample obtained by combustion method is 159330 and that of sample by pyrolysis is $39008 . \mathrm{CaCu}_{3} \mathrm{Ti}_{4} \mathrm{O}_{12}$ has a giant dielectric constant up to $10^{5}$ at room temperature and great potential for technological application.

Swatsitang et al. [51] successfully prepared $\mathrm{CaCu}_{3} \mathrm{Ti}_{4} \mathrm{O}_{12}$ (ССТO) nanoparticles by a simple polymer pyrolysis method. The XRD results show that both of the calcined powders at a low temperature $800{ }^{\circ} \mathrm{C}(\mathrm{CCTO}-1)$ and $850{ }^{\circ} \mathrm{C}$ (CCTO-2) in air for $4 \mathrm{~h}$ have pure perovskite structure. The crystallite sizes, as evaluated by the XRD line broadening technique are 47.5 and $75.0 \mathrm{~nm}$, respectively. The particle sizes as estimated from the bright field images of TEM were found to be in the range of 10-35 and 7-52 nm for CCTO-1 and CCTO-2, respectively, and are shown in Figure 17.

The dielectric measurement of the pellet sintered at $1,050{ }^{\circ} \mathrm{C}$ in air for $6 \mathrm{~h}$ (CCTO-2A) having the values of dielectric constant $\left(\varepsilon^{\prime}\right)$ and the low loss tangent $(\tan \delta)$ at $1 \mathrm{kHz}$ and $20{ }^{\circ} \mathrm{C}$ were found to be 11,472 and 0.0438 , respectively, at this temperature. The giant dielectric constant and $\tan \delta$ values are suggested to be closely related to its microstructural density, calcination temperature and the Maxwell-Wagner polarization.

Precipitation method: The solution-based methods offer the advantages of optimum particle size and phase purity. Barbier et al. [52] studied the electrical properties of $\mathrm{CaCu}_{3} \mathrm{Ti}_{4} \mathrm{O}_{12}$-based pellets and thick films obtained from the similar raw precursor prepared by the co-precipitation method.The metal chlorides $\left(\mathrm{CaCl}_{2}, \mathrm{TiCl}_{3}\right.$ and $\left.\mathrm{CuCl}_{2} \cdot 2 \mathrm{H}_{2} \mathrm{O}\right)$ were dissolved in water and then poured in ethanol-containing oxalic acid used as the precipitating agent. In order to obtain oxide powders, these precursors were calcined in air at $950{ }^{\circ} \mathrm{C}$ for $10 \mathrm{~h}$ and the dielectric characteristics of pellets and thick films were compared.The pellets exhibit high values of the dielectric permittivity $\left(\varepsilon_{\mathrm{r}} \sim 1.4 \times 10^{5}\right)$ and relatively small dielectric losses (tan $\delta \sim 0.16$ ) at $1 \mathrm{kHz}$ and room temperature. ССTO thick films present very high values of their dielectric permittivity $\left(\varepsilon_{\mathrm{r}} \sim 5 \times 10^{4}\right)$ even if they are lower than the one of the ССTO pellets. From a physical point of view the difference in copper content and grain size, and possibly various oxidation states may explain the changes in the dielectric permittivity between films and pellets. This result, which is

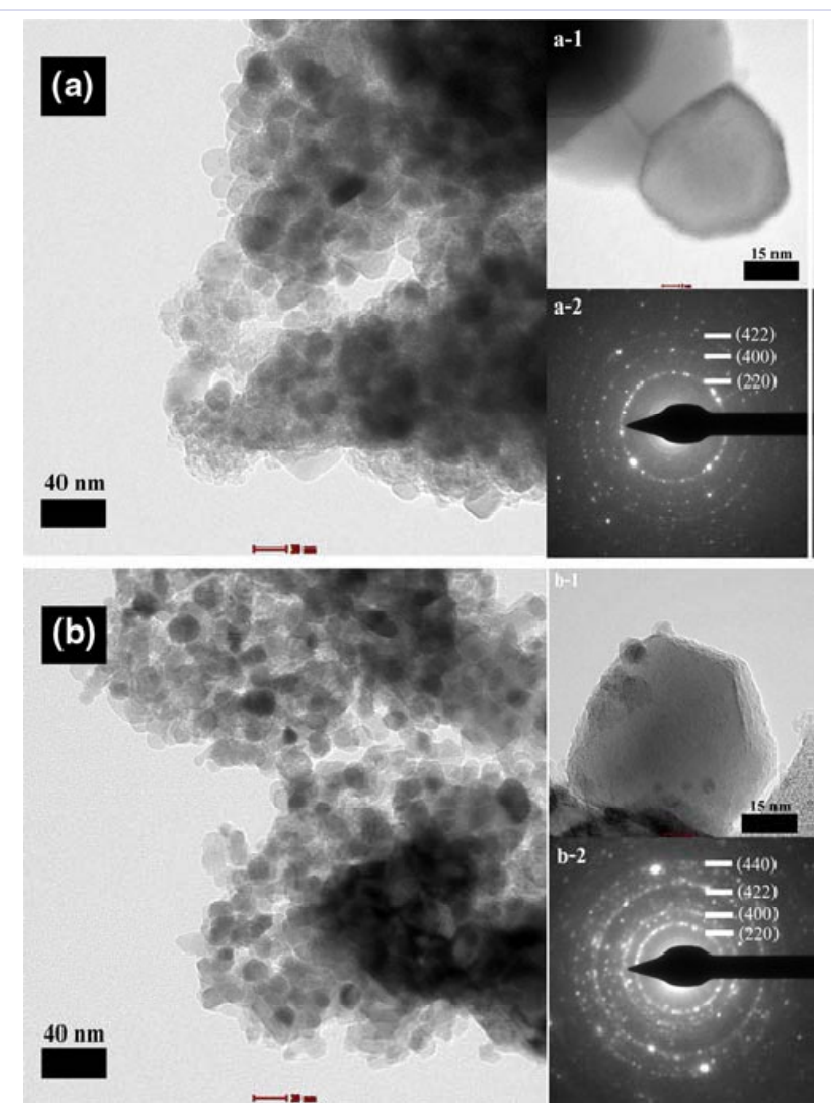

Figure 17: Low resolution TEM images of the CCTO-1 (a) and CCTO-2 (b) powder samples. Insets (a-1, b-1) and (a-2, b-2) are the high resolution TEM images and SAED of the CCTO-1 and CCTO- 2 powder samples, respectively [51]. 
strongly related to the nature of the dielectric material in between the electrodes, constitutes a strong indication that the high dielectric permittivity values observed in this material are not related to an interfacial (electrode material) related mechanism but is an internal barrier layer capacitor (IBLC) type.

Thomas et al. [53] developed a wet chemical method for the preparation of complex oxalate precursor, $\mathrm{CaCu}_{3}(\mathrm{TiO})_{4}\left(\mathrm{C}_{2} \mathrm{O}_{4}\right)_{8} \cdot 9 \mathrm{H}_{2} \mathrm{O}$ which gives rise to nano-crystalline phase pure $\mathrm{CaCu}_{3} \mathrm{Ti}_{4} \mathrm{O}_{12}$ (CCTO) powders with a crystallite size varying from 30 to $200 \mathrm{~nm}$ when heat treated at $680^{\circ} \mathrm{C}$. The phase singularity of the complex oxalate precursor is confirmed by the wet chemical analyses, X-ray diffraction, FT-IR and TGA/ DTA analyses. The UV-vis reflectance and ESR spectra of CCTO powders indicate that the $\mathrm{Cu}(\mathrm{II})$ coordination changes from distorted octahedra to nearly flattened tetrahedra (squashed) to square-planar geometry with increasing annealing temperature. TEM images of the phase-pure CCTO powders obtained from the thermal decomposition of the oxalate precursor at $700-900^{\circ} \mathrm{C}$ (Figure18), reveal apparent micro-structural features (Figure $18 \mathrm{a}-\mathrm{c}$ ). There are particles with curved (Figure 18d) edges and corners. The particles are weakly agglomerated (Figure 18d)

The micro-structural features as revealed by the HRTEM in nano-scale indicate that $\mathrm{CuO}_{4}$ groups with the squashed tetrahedral geometry are more prevalent in the exterior regions of the powder particles as compared to the predominance of square-planar $\mathrm{CuO}_{4}$ in the interior. The powders derived from the oxalate precursor have excellent sinter ability, resulting in highdensity ceramics which exhibited giant dielectric constants up to $40,000(1 \mathrm{kHz})$ at $25^{\circ} \mathrm{C}$, accompanied by low dielectric loss 0.07 .

Marchin et al. [54] synthesized the $\mathrm{CaCu}_{3} \mathrm{Ti}_{4} \mathrm{O}_{12}$ oxide by the
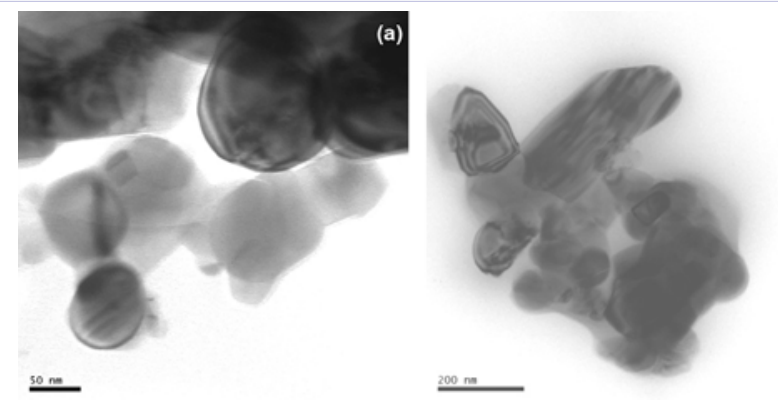

(b)

(c)

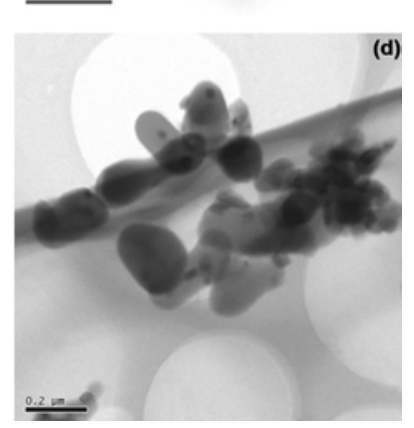

Figure 18: TEM images of phase-pure CCTO obtained at $680^{\circ} \mathrm{C}(\mathrm{a}-\mathrm{c})$ and (d) weakly agglomerated particles (curvededges and corners) [53]. oxalate precursors. Oxalate precursors are obtained by the coprecipitation of calcium, copper and titanium chlorides with oxalic acid. XRD analysis revels that the co-precipitation method allowed to obtain and to control the partition of several phases in addition to pure CCTO. The amount of these phases is simply controlled by varying the ratio of the reactants introduced during the synthesis. The SEM micrographs of the precursor powders reveal a disc-like morphology with an average diameter of 2-3 $\mu \mathrm{m}$ and a thickness of 300-400 $\mathrm{nm}$. After decomposition, the oxide powders are obtained in homogeneous grains shape with size ranging from 0.2 to $1 \mu \mathrm{m}$.

Zhao et al. [55] synthesized the $\mathrm{CaCu}_{3} \mathrm{Ti}_{4} \mathrm{O}_{12}$ powders by basic co-precipitation method at $1100{ }^{\circ} \mathrm{C}$ for $10 \mathrm{~h}$ using polyethylene glycol (PEG) as suitable capping agent during coprecipitation procedure. SEM images of the precursor and calcined CCTO containing different amounts of PEG. Quasispherical CСTO powders with uniform diameter distribution of about $0.5-1.0 \mu \mathrm{m}$, regardless of small trails of agglomeration, were obtained without PEG dispersant. With the addition of PEG, CCTO powders arranged in a certain direction and the grain size became smaller, about100-200nm. The mechanism of the unique architectures formation maybe attributed to the role of PEG in growth rates control of different crystal faces through adsorption and desorption. The value of dielectric constant for samples containing PEG are smaller than pure CCTO because of small and in homogeneous grain size and permittivity shows little frequency dependence from 1000 to $10^{5} \mathrm{~Hz}$ while the pure ССТO ceramics decreases sharply with frequencybelow $10^{4} \mathrm{~Hz}$, especially in the range of $100-10^{3} \mathrm{~Hz}$.

Sen et al. [56] successfully synthesized single-crystalline CCTO nanostructures for the first time by a novel and convenient molten salt route. Calcium acetate, copper acetate, titanium dioxide (anatase) were taken as the precursors for CCTO while $\mathrm{NaCl}-\mathrm{KCl}$ mixture $\left(1: 1\right.$ molar ratio, m.p.: $\left.657^{\circ} \mathrm{C}\right)$ was used as the reaction medium.The technique is not only blessed with high yield but also can readily generate a wide range of morphologies from nano-particles, nano-cubes to nano-rods in reproducible way.XRD pattern of the sample synthesized at $800^{\circ} \mathrm{C}$ for $5 \mathrm{~h}$ were identical ССТO phase. The phase and morphology of the resultant products are sensitive to both reaction time and to the ratio of ССTO precursors to mixed chlorides. By minor adjustment of the controlling parameters, single-crystalline CCTO nano-structures can be obtained. The synthesized nanostructures, irrespective of their shapes, maintain single-crystalline character as it is evident from high-resolution transmission electron microscopic studies.

The present study will pave the way for the development of single-crystalline multi-component perovskitenano-structures, which were seem to be extremely hard to realize to date and expect our pathway to open up new direction for the synthesis of other multi-functional perovskite oxides single- crystalline nanostructures.

Hydrothermal processing: Hydrothermal synthesis is generally defined as crystal synthesis or crystal growth under high temperature and high pressure water conditions from substances which are insoluble in ordinary temperature and 
pressure $\left(<100^{\circ} \mathrm{C},<1 \mathrm{~atm}\right)$. The critical temperature and pressure of water are $374^{\circ} \mathrm{C}$ and $22.1 \mathrm{MPa}$, respectively. The solvent properties for many compounds, such as dielectric constant and solubility, change dramatically under supercritical conditions [57]. There are only few reports on hydrothermal process because sintering temperature of CCTO required $\leq 1100^{\circ} \mathrm{C}$ to produce single phase.

Keat et al. [58] synthesized $\mathrm{CaCu}_{3} \mathrm{Ti}_{4} \mathrm{O}_{12}$ using hydrolysis and subsequent condensation into a hydrous $\mathrm{TiO}_{2}$ gel which was obtained by adding $\mathrm{C}_{4} \mathrm{H}_{9} \mathrm{OH}$ diluted $\mathrm{Ti}\left(\mathrm{OC}_{4} \mathrm{H}_{9}\right)$ drop-wise into water under stirring. Peptization was done by adding appropriate amounts of $\mathrm{HNO}_{3}$ to form a translucent $0.4 \mathrm{M} \mathrm{TiO}_{2}$ sol with a solution of $\mathrm{pH}$ of 1 . Appropriate amounts of $\mathrm{Ca}\left(\mathrm{NO}_{3}\right)_{2}$ and $\mathrm{Cu}\left(\mathrm{NO}_{3}\right)_{2}$ were then added in it. Due to the differences in the solubilities of the $\mathrm{Ca}, \mathrm{Cu}$ and $\mathrm{Ti}$, initial variations from ideal stoichiometry and a high solution $\mathrm{pH}$ was necessary to obtain stoichiometric $\mathrm{CaCu}_{3} \mathrm{Ti}_{4} \mathrm{O}_{12}$ precipitates. The precipitate was sintered at $850^{\circ} \mathrm{C}$ and XRD peaks corresponding to the cubic CCTO phase were observed. The microstructures of the sintered CCTO, after polishing and thermal etching, the grain size estimated via automated image analysis was $0.7969 \mu \mathrm{m}$ while the circular intercept method shows the grain size to be approximately $0.8623 \mu \mathrm{m}$ which was in the submicron range.

\section{Semi wet method}

Singh et al. [59] synthesized nano-structured $\mathrm{CaCu}_{2.90} \mathrm{Zn}_{0.10} \mathrm{Ti}_{4} \mathrm{O}_{12}$ (CCZTO) electro- ceramic by semi-wet route and the pellets were sintered at $950^{\circ} \mathrm{C}$ for $6 \mathrm{~h}, 8 \mathrm{~h}$ and $12 \mathrm{~h}$ in air. The ceramics exhibit high dielectric constant of $1.35 \times 10^{4}$ at $1 \mathrm{kHz}$. The crystallite size of the CCZTO ceramic, obtained by XRD using Debye Scherer formula, range from 38-74nm which is in good agreement with the particle size observed by TEM analysis. It was observed clearly that the grain size significantly increased with an increase in sintering duration. Dielectric constant increases with increasing sintering time and dielectric loss decreases. It is suggested that the longer sintering time may lead to more defect structures. The increase in particle size with increasing sintering time is shown in Figure 19. It is mainly due to formation of large size particles as a result of loss of grain boundaries of small size particles. These changes lead to stability to the large size particles due to loss in grain boundary.

Singh et al. [60] studied the effect of doping $\mathrm{Mg}^{2+}$ at $\mathrm{Cu}^{2+}$ site in $\mathrm{CaCu}_{3} \mathrm{Ti}_{4} \mathrm{O}_{12}$ synthesized by modified sol-gel route using solid $\mathrm{TiO}_{2}$ powder. XRD analysis confirmed the formation of singlephase material, and the structure did not change on doping of $\mathrm{Mg}$ and it remained cubic similar to $\mathrm{CaCu}_{3} \mathrm{Ti}_{4} \mathrm{O}_{12}$ (CCTO).The average particle size in sintered powder of the ceramic obtained from XRD and transmission electron microscopy (TEM) was found to be $59 \pm 05 \mathrm{~nm}$ and $90 \pm 25 \mathrm{~nm}$, respectively.

SEM image shows the presence of bimodal grains while EDX analysis confirmed copper oxide rich phase at the grain boundary. An exceptionally very high dielectric constant 86,084 at $500 \mathrm{~K}$ on partially substituted $\mathrm{Mg}^{2+}$ at $\mathrm{Cu}$-site in CCTO ceramic at $1 \mathrm{kHz}$ was observed. The nature of relaxation behavior of the ceramic was also rationalized by impedance and modulus spectroscopic
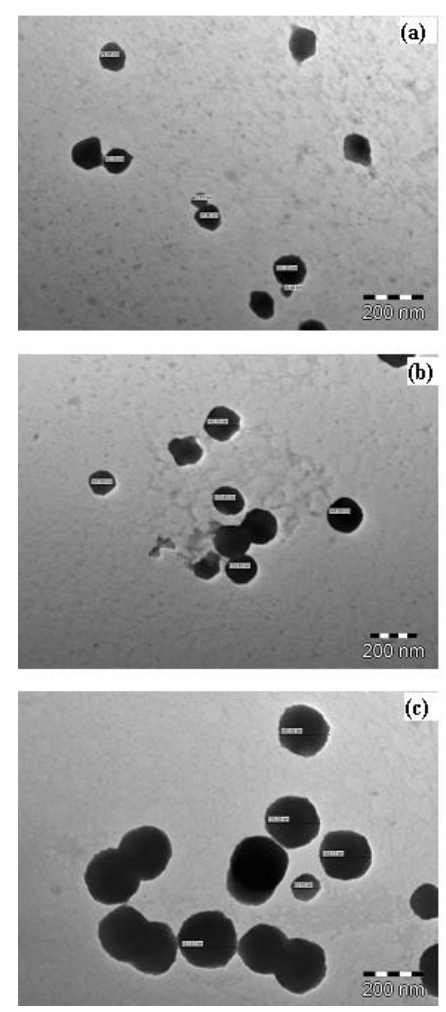

Figure 19: TEM images of $\mathrm{CaCu}_{2.90} \mathrm{Zn}_{0.10} \mathrm{Ti}_{4} \mathrm{O}_{12}$ ceramics sintered at $950^{\circ} \mathrm{C}$ for (a) $6 \mathrm{~h} \mathrm{(b)} 8 \mathrm{~h}$ and (c) $12 \mathrm{~h}$ [59].

analysis. Modulus spectroscopic studies confirmed the MaxwellWagner relaxation arising due to the interfaces between grain and grain boundary.

Mandal et al. [61] studied the effect of doping at $\mathrm{Ti}^{4+}$ site by $\mathrm{Ce}^{3+}$ using $\mathrm{CaCu}_{3} \mathrm{Ti}_{3.90} \mathrm{Ce}_{0.10} \mathrm{O}_{12}$ synthesized by citrate-gel route. DTA/TG analysis of dry powder gives pre-information about formation of final product around $850^{\circ} \mathrm{C}$. XRD analysis confirmed the formation of $\mathrm{CaCu}_{3} \mathrm{Ti}_{3.90} \mathrm{Ce}_{0.10} \mathrm{O}_{12}$ phase of the ceramic sintered at $950^{\circ} \mathrm{C}$ for $12 \mathrm{hrs}$. Microstructure studied using Scanning Electron Microscopy (SEM) confirmed the average grain size in the nano range, $200 \mathrm{~nm}-400 \mathrm{~nm}$ (Figure 20).The nature of relaxation behavior of ceramic was also rationalized using the impedance and modulus spectroscopy. While the bulk conductivity indicates an Arrhenius-type thermally activated process, the ac conductivity spectrum obeyed the Jonscher power law. The complex impedance diagrams of the ceramic exhibited a significant contribution from the grains, grain boundaries and electrode. The activation energies calculated from the grainboundary relaxation time constant was found to be $0.49 \mathrm{eV}$ which confirmed the Maxwell-Wagner type of relaxation in the ceramic.

Singh et al. [62] synthesized nano-crystalline electro-ceramic $\mathrm{s}, \mathrm{CaCu}_{2.90} \mathrm{Zn}_{0.10} \mathrm{Ti}_{4} \mathrm{O}_{12}$ (CCZTO), by solution-wet route (SR) as well as semi-wet route using citric acid (SWR1) and Glycine (SWR2) separately, and were characterized by TGA/DTA, XRD, TEM, SEM and EDX techniques. The crystallite size of the ceramics obtained by XRD were found to be in the range of $45-90 \mathrm{~nm}$ in good agreement with those observed by TEM analysis shown in Figure 


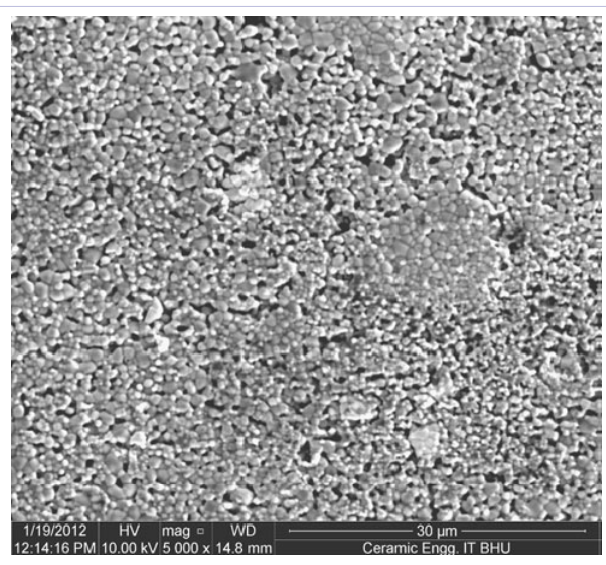

Figure 20: $\mathrm{SEM}$ micrograph of $\mathrm{CaCu}_{3} \mathrm{Ti}_{3.90} \mathrm{Ce}_{0.10} \mathrm{O}_{12}$ sintered at $950^{\circ} \mathrm{C}$ for $12 \mathrm{~h}[61]$.

21. The grain sizes for the ceramics SWR1, SWR2 and SR observed by SEM were found to be in the range of $10-15 \mu \mathrm{m}, 1-4 \mu \mathrm{m}$, and 2-4 $\mu \mathrm{m}$, respectively. Thermal studies show that the single phase CCZTO ceramic was formed in single step combustion reaction in SWR2 while in the case of SWR1 and SR they were obtained in multi-step reactions. SWR2 route shows more effective solid state reaction for the formation of nano-crystalline CCZTO single phase at much lower sintering temperature.

Singh et al. [63] also studied the ultrafine powders of $\mathrm{CaCu}_{2.80} \mathrm{Zn}_{0.20} \mathrm{Ti}_{4} \mathrm{O}_{12}$, synthesized by the novel semi-wetroute using metal nitrate solution and solid $\mathrm{TiO}_{2}$ powder.DTA/TG analysis of dry powder gives pre-information about formation of final product around $800^{\circ} \mathrm{C}$. Single-phase formation was confirmed by $\mathrm{XRD}$ sintered at $950^{\circ} \mathrm{C}$ for $12 \mathrm{~h}$ which is much lower temperature compared to conventional ceramic method. The particle size of the ceramic was found in the nano-size range. The average particle size of sintered powder of the ceramic obtained from XRD and Transmission electron microscopy in Fig. 22 was found to be $59 \mathrm{~nm}$ and $102 \mathrm{~nm}$, respectively.

Energy Dispersive X-ray studies confirm the stoichiometry and purity of the synthesized ceramic. The value of dielectric constant and dielectric loss of the ceramic was found to be 2031 and 0.353 , respectively, which are nearly temperature independent at $100 \mathrm{kHz}$.

\section{Conclusion}

The urgent demand for high dielectric constant ceramic capacitors has been a key issue leading to the development of capacitor technology. In view of this the scientists and technologists have shown potential interest to obtain $\mathrm{CaCu}_{3} \mathrm{Ti}_{4} \mathrm{O}_{12}$ (ССTO) and its cation substituted isomorphs with high dielectric constant and low loss values. The critical success of new ССТО materials lies in their preparation which controls the morphology, particle size and its dielectric properties. In order to obtain these features, small particle size, narrow size distribution, uniform morphology, optimum crystallinity degree, high specific surface area, minimum defects and agglomeration, and homogeneous metal doping are required for the practical applications of
$\mathrm{CaCu}_{3} \mathrm{Ti}_{4} \mathrm{O}_{12}$ powders in capacitor. The only limitation which restricts the broad applications of this compound is the dielectric loss. Methods described in this overview were designed to obtain $\mathrm{CaCu}_{3} \mathrm{Ti}_{4} \mathrm{O}_{12}$ nano-crystalline powders with desired structures and high dielectric constant. Since the number of surface atoms or ions becomes a significant fraction of their total number, and the surface energy plays an important role in the thermal stability and crystal structure, the materials in the nanometer size range exhibit some remarkable properties which can be exploited to get high dielectric constant and low loss CCTO.
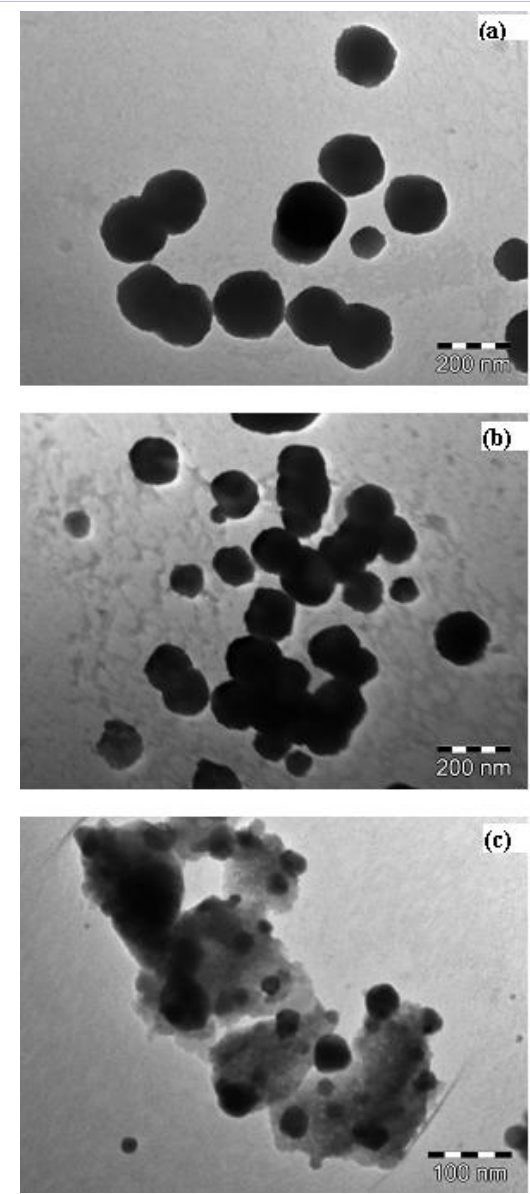

Figure 21: TEM images of (a) SWR1 (b) SWR2 and (c) SR synthesized by diverse routes sintered at $950^{\circ} \mathrm{C}$ for $12 \mathrm{~h}$ [62].

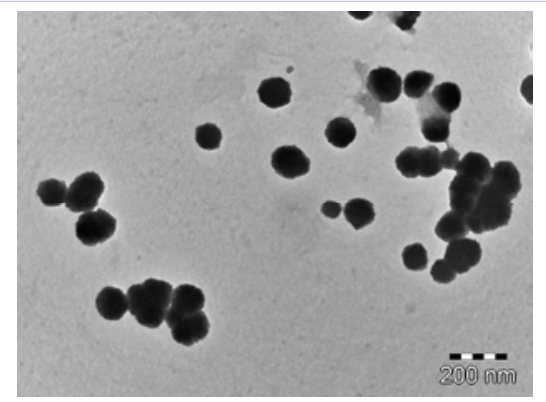

Figure 22: TEM image of $\mathrm{CaCu}_{2.80} \mathrm{Zn}_{0.20} \mathrm{Ti}_{4} \mathrm{O}_{12}$ sintered at $950^{\circ} \mathrm{C}$ for 12 h. [63]. 
Although solid-state synthesis is an established conventional route to obtain well-crystallized particles of CCTO with ordered structure, it requires high treatment temperature and longer process time leading to larger particle size and high dielectric constant and low dielectric loss. Uncontrollable particle growth and agglomeration, associated with solid-state synthesis can be partially suppressed using sol-gel methods. However, there is a need for new synthetic methods which reduce energy consumption, cost, and processing time. The solution chemistry methods with focus on sol-gel method and basic co-precipitation synthesis give high purity, small particle size, uniform size distribution, and hence desirable dielectric properties. Most probably the sol-gel method which is highlighted in this overview may develop into a commercial viable approach to the production of large scale CCTO nano-crystalline powders for use in device applications. Several methods have been reported by various researchers to prepare nano-size CCTO and similar ceramic with high dielectric constant. Among these the most adopted solid state reaction method lacks in terms of homogeneity of precursor materials. In addition, the process requires higher sintering temperature and longer sintering time for solid state diffusion to occur for single phase-formation. Wet chemical synthesis routes, such as sol-gel, hydrothermal/solvothermal, or co-precipitation methods, have more advantages over solidstate reactions in achieving better homogeneity and mixing of the starting compounds on molecular level. The semi-wet method using aqueous metal nitrate solutions and solution of oxide of titanium along with oxalic acid as complexing agent at lower sintering temperature in shorter sintering time is the current approach for the synthesis of the best quality nano-СCTO and its isomorphs and similar ceramic materials.

\section{Acknowledgement}

Authors are grateful to Prof. Om Parkash, Department of ceramic Engineering, IIT (BHU) and Prof. R.K. Mandal, Department of Metallurgical Engineering, IIT (BHU) for their fruitful discussions on SEM and TEM analysis.

\section{References}

1. Deschanvres A, Raveau B, Tollemer F (1967) Substitution of copper for a divalent metal in perovskite-type titanates. Bull Chim Fr 11: 4077-4078

2. Bochu B, Deschizeaux MN, Joubert JC, Collomb A, Chenavas J, Marezio M (1978) Synthese et caracterisation dune serie de titanates perowskites isotypes de $\mathrm{CaCu}_{3} \mathrm{Mn}_{4} \mathrm{O}_{12}$. Journal of Solid State Chemistry 29: 291-298.

3. Adams TB, Sinclair DC, West AR (2006) Characterization of grain boundaryimpedences in fine- and coarse-grained $\mathrm{CaCu}_{3} \mathrm{Ti}_{4} \mathrm{O}_{12}$ ceramics. Physical Review B 73: 094124-094133.

4. Singh L, Rai US, Mandal KD (2013) Dielectric, modulus and impedance spectroscopic studies of nanostructured $\mathrm{CaCu}_{2.70} \mathrm{Mg}_{0.30} \mathrm{Ti}_{4} \mathrm{O}_{12}$ electroceramic synthesized by modified sol-gel route. Journal of Alloys and Compounds 555: 176-183.

5. Subramanian MA, Dong L, Duan N, Reisner BA (2000) High dielectric in $\mathrm{ACu}_{3} \mathrm{Ti}_{4} \mathrm{O}_{12}$ and $\mathrm{ACu}_{3} \mathrm{Ti}_{3} \mathrm{FeO}_{12}$ phases. Journal Solid State Chemistry 151: $323-325$.
6. Thamas P, Dwarkanath K, Varama KBR, Kutty TRN (2008) Nanoparticles of the giant dielectric material, $\mathrm{CaCu}_{3} \mathrm{Ti}_{4} \mathrm{O}_{12}$ from a precursor route. Journal of Physics and Chemistry of Solids 69: 25942604.

7. West AR, Adams TB, Morrison FD, Sinclair DC (2004) Novel high capacitance materials:- $\mathrm{BaTiO}_{3}: \mathrm{La}$ and $\mathrm{CaCu}_{3} \mathrm{Ti}_{4} \mathrm{O}_{12}$. Journal of European Ceramic Society 24: 1439-1448.

8. Grubbs RK, Venturini EL, Clem PG, Richardson JJ, Tuttle BA etal.(2005) Dielectric and magnetic properties of $\mathrm{Fe}$ - and $\mathrm{Nb}$-doped $\mathrm{CaCu}_{3} \mathrm{Ti}_{4} \mathrm{O}_{12}$ Physical Review B 72:104111.

9. Chen H, Cong TN, Yang Y,Tan C, Li Y, etal. (2009) Progress in electrical energy storage system: A critical review. Progress in Natural Science: Materials International 19: 291-312.

10. Liu J, Smith RW, Mei WN (2007) Synthesis of the Giant Dielectric Constant Material $\mathrm{CaCu}_{3} \mathrm{Ti}_{4} \mathrm{O}_{12}$ by Wet-Chemistry Methods. Chemistryof Materials 19: 6020-6024.

11. Jin S, Xia H, Zhang Y, Guo J, Xu J (2007) Synthesis of $\mathrm{CaCu}_{3} \mathrm{Ti}_{4} \mathrm{O}_{12}$ ceramic via a sol-gel method.Material Letter 61: 1404-1407.

12. Jhu BP, Wang ZY, Zhang Y, Zhisong Y, Shi J, etal. (2009) Low temperature fabrication of the giant dielectric material $\mathrm{CaCu}_{3} \mathrm{Ti}_{4} \mathrm{O}_{12}$ by oxalate co-precipitation method. Material Chemistry and Physics 113: 746-748.

13. Hutagalung SD, Ikhawan M Ibrahim M, Ahmad ZA (2008) Microwave assisted sintering of $\mathrm{CaCu}_{3} \mathrm{Ti}_{4} \mathrm{O}_{12}$.Ceramic International 34(4): 939942 .

14. Cai J, Lin YH, Cheng B, Nan CW, He J,etal. (2007) Dielectric and nonlinear electrical behavior observed in $\mathrm{Mn}$-doped $\mathrm{CaCu}_{3} \mathrm{Ti}_{4} \mathrm{O}_{12}$ ceramic. Applied Physics Letter 91(5): 252905-(3 pages).

15. Mu C, Jhang H, He Y, Liu P, Shen J (2009) The origin of multiple dielectric relaxation processes in Fe-substituted $\mathrm{CaCu}_{3} \mathrm{Ti}_{4} \mathrm{O}_{12}$ ceramics. Material ScienceEngineering B. 162: 195-199.

16. Li W, Qui S, Chen N, Du G (2010) Enhanced Dielectric Response in Mg-doped $\mathrm{CaCu}_{3} \mathrm{Ti}_{4} \mathrm{O}_{12}$ Ceramics. Journal ofMaterial Science and Technology 26(8): 682-686.

17. Xu D, Jhang C, Cheng XN, Fan Y, Yang T,etal. (2011) Dielectric properties of Zn Doped CCTO Ceramics by Sol-Gel Method. Advanced Material Research 197: 302-305.

18. Fang TT, Shiau HK (2004) Mechanism for Developing the Boundary Barrier Layers ofCaCu $\mathrm{Ti}_{4} \mathrm{O}_{12}$. Journal of American Ceramic Society 87: 2072-2079.

19.Singh L, Rai US, Mandal KD (2012) Influence of Zn-doping on the Microstructures and Dielectric Properties in $\mathrm{CaCu}_{3} \mathrm{Ti}_{4} \mathrm{O}_{12}$ Ceramic Synthesized by Semi -wet route. Advances in Applied Ceramics 111: 374-380.

20.Singh L, Rai US, Mandal KD, Yashpal M (2012) Dielectric properties of ultrafine $\mathrm{Zn}$ doped $\mathrm{CaCu}_{3} \mathrm{Ti}_{4} \mathrm{O}_{12}$ ceramic. Journal of advanced dielectrics 02: 1-6.

21. Singh L, Rai US, Rai AK, Mandal KD (2013) Sintering effects on dielectric properties of $\mathrm{Zn}$ - doped $\mathrm{CaCu}_{3} \mathrm{Ti}_{4} \mathrm{O}_{12}$ ceramic synthesized by modified sol-gel route. Electronic Material Letter 9: 107-113.

22. Singh L, Rai US, Mandal KD (2013) Dielectric, Modulus and Impedance spectroscopic studies of nanostructured $\mathrm{CaCu}_{270} \mathrm{Mg}_{0^{*} 30} \mathrm{Ti}_{4} \mathrm{O}_{12}$ electroceramic synthesized by modified sol-gel route. Journal of Alloys and Compounds 555: 176-183.

23. Singh L, Rai US, Rai AK, Mandal KD (2013) Effects of partial substitutions of transition metal cations on dielectric properties of $\mathrm{Ca}_{1}$ 
$\mathrm{La}_{\mathrm{x}} \mathrm{Cu}_{3-\mathrm{x}} \mathrm{Mn}_{\mathrm{x}} \mathrm{Ti}_{4-\mathrm{x}} \mathrm{Ni}_{\mathrm{x}} \mathrm{O}_{12}(\mathrm{x}=0.05,0.10)$ electro-ceramics synthesized by semi-wet chemical method. Journal of Advanced Ceramics 2: 119-127.

24.Jha P, Arora P, Ganguli AK (2003) Polymeric citrate precursor route to the synthesis of the high dielectric constant oxide, $\mathrm{CaCu}_{3} \mathrm{Ti}_{4} \mathrm{O}_{12}$. Material Letter 57: 2443-2446.

25. Liu J, Smith RW, Mei WN (2007) Synthesis of the Giant Dielectric Constant Material $\mathrm{CaCu}_{3} \mathrm{Ti}_{4} \mathrm{O}_{12}$ by Wet-Chemistry Methods.Chemistry of Materials 19(24): 6020-6024.

26. Masingbon C, Thongbai P, Maensiri S, Yamwong T, Seraphin S (2008) Synthesis and giant dielectric behavior of $\mathrm{CaCu}_{3} \mathrm{Ti}_{4} \mathrm{O}_{12}$ ceramics prepared by polymerized complex method. Material Chemistry Physics 109: 262-270.

27.Pechini MP (1967) U.S. Patent, 3 July, 330: 697.

28.Chick LA, Pederson LR, Maupin GD, Bates JL, Thomas LE,etal. (1990) Glycine-nitrate combustion synthesis of oxide ceramic powders. Material Letter 10: 6-12.

29. Singh L, Rai US, Mandal KD (2013) Dielectric properties of zinc doped nano-crystalline calcium copper titanate synthesized by different approach. Materials Research Bulletin 48: 2117-2122.

30.IEEE International Conference on Solid Dielectrics, Bologna, Italy, June 30 - July 4, 2013.

31. Masingboon C, Maensiri S, Yamwong T, Anderson PL, S Seraphin (2008) Nanocrystalline $\mathrm{CaCu}_{3} \mathrm{Ti}_{4} \mathrm{O}_{12}$ powders prepared by egg white solution route: synthesis, characterization and its giant dielectric properties. Applied Physics A 91(1): 87-95.

32.Thomas P, Dwarakanath K, Varma KBR, Kutty TRN (2009) Synthesis of nanoparticles of the giant dielectric material, $\mathrm{CaCu}_{3} \mathrm{Ti}_{4} \mathrm{O}_{12}$ from a precursor route. Journal of Thermal Analysis and Calorimetry 95(1): 267-272.

33.Sen S, SahuP, Prasad K, (2010) A novel technique for the synthesis of $\mathrm{CaCu}_{3} \mathrm{Ti}_{4} \mathrm{O}_{12}$ ceramics. Materials Science-Poland 28: 265-271.

34.Banerjee Nirupam, Krupanidhi, Saluru Baba (2010) Synthesis, structural characterization and formation mechanism of giantdielectric $\mathrm{CaCu}_{3} \mathrm{Ti}_{4} \mathrm{O}_{12}$ nanotubes. Natural Science 2(7): 688-693.

35.Amaral F, Valente M, Costa LC (2011) Physical properties of $\mathrm{CaCu}_{3} \mathrm{Ti}_{4} \mathrm{O}_{12}$ obtained from different EDTA-gel derived powders. Physica Status Solidi a 208(10): 2284-2287.

36. Kumar C (2011) Dielectric properties of $\mathrm{CaCu}_{3} \mathrm{Ti}_{4} \mathrm{O}_{12}$ prepared by solgel self combustion Technique. Journal of Material Science Material in Electronics 22(6): 579-582.

37. Kumar R, Zulfequar M, Kaur H, Singh VN, Senguttuvan TD (2011) Impedance Spectroscopic St udies of Sol-Gel Derived Nanocrystalline $\mathrm{CaCu}_{3} \mathrm{Ti}_{4} \mathrm{O}_{12}$. Advanced Science, Engineering and Medicine 3(3): 197201.

38.Jesurani S, Kanagesan S, Velmurugan R, Thirupathi C, Sivakumar M, et al. (2011) Nanoparticles of the giant dielectric material, calcium copper titanate from a sol-gel Technique. Materials Letters 65: 33053308.

39.Tian Y, Zhang X, Yang Y, Liu Z, Huang X (2011) Sol-Gel Synthesis and sensing Study of Perovskite $\mathrm{CaCu}_{3} \mathrm{Ti}_{4} \mathrm{O}_{12}$ Nanopowders. Integrated Ferroelectrics 129: 188-195.

40.Vangchangyia S, Swatsitang E, Thongbai P, Pinitsoontorn S, Yamwong T, et al. (2012) Very Low Loss Tangent and High Dielectric Permittivity in Pure- $\mathrm{CaCu}_{3} \mathrm{Ti}_{4} \mathrm{O}_{12}$ Ceramics prepared by a Modified Sol-Gel Process. Journal of American Ceramic Society 95(5): 1497-1500.
41.Jesurani S, Kanagesan S, Ashok K (2012) Microstructure and dielectrical responses of pure and Cobalt doped $\mathrm{CaCu}_{3} \mathrm{Ti}_{4} \mathrm{O}_{12}$ ceramics by sol-gel synthesis route. Journal of Sol-Gel Science and Technology 64: 335-341.

42.Zhao J, Liu J, Ma G (2012) Preparation, characterization and dielectric properties of $\mathrm{CaCu}_{3} \mathrm{Ti}_{4} \mathrm{O}_{12}$ Ceramics. Ceramics International 38: 12211225.

43. Banerjee N, Krupanidhi SB (2013) Low dimensional fabrication of giant dielectric $\mathrm{CaCu}_{3} \mathrm{Ti}_{4} \mathrm{O}_{12}$ through soft e-beam lithography. Journal of Alloys and Compounds 547:147-151.

44. Jesurani S, Kanagesan S, Hashim M, Ismail I, (2013) Dielectric properties of $\mathrm{Zr}$ doped $\mathrm{CaCu}_{3} \mathrm{Ti}_{4} \mathrm{O}_{12}$ synthesized by sol-gel route. Journal of Alloys and Compounds 551: 456-462.

45. Xu D, Zhang C, Lin Y, Jiao L, Yuan H, et al. (2012) Influence of zinc on electrical and micro structural properties of $\mathrm{CaCu}_{3} \mathrm{Ti}_{4} \mathrm{O}_{12}$ ceramics prepared by sol-gel process. Journal of Alloys and Compounds 522: $157-161$.

46. Banerjee N, Krupanidhi SB (2011) An aqueous-solution based lowtemperature pathway to synthesize giant dielectric $\mathrm{CaCu}_{3} \mathrm{Ti}_{4} \mathrm{O}_{12}$ Highly porous ceramic matrix and submicron sized powder. Journal of Alloys and Compounds 509(12): 4381-4385.

47. Wang MH, Zhang B, Zhou F, Yao C (2014) Microstructure and dielectric properties of $\mathrm{Nd}$ Doped $\mathrm{CaCu}_{3} \mathrm{Ti}_{4} \mathrm{O}_{12}$ synthesized by sol-gel method. Journal of Sol-Gel Science and Technology 69: 281-287.

48. Sangwong N, Yamwong T, Thongbai P (2013) Synthesis, characterization and giant dielectric properties of $\mathrm{CaCu}_{3} \mathrm{Ti}_{4} \mathrm{O}_{12}$ ceramics prepared by a polyvinyl pyrrolidone-dimethylformamide solution route. Journal of Electro-ceramic 31: 181-188.

49. Liu J, Sui Y, Duan C, Mei WN, Smith RW, et al. (2006) $\mathrm{CaCu}_{3} \mathrm{Ti}_{4} \mathrm{O}_{12}$ : LowTemperature Synthesis by Pyrolysis of an Organic Solution. Chemistry of Materials18: 3878-3882.

50. Liu J, Smith RW, Mei WN et al, (2007) Synthesis of the Giant Dielectric Constant Material $\mathrm{CaCu}_{3} \mathrm{Ti}_{4} \mathrm{O}_{12}$ by Wet-Chemistry Methods. Chemistry of Materials 19(24): 6020-6024.

51. Swatsitang E, Niyompan A, Putjuso T (2013) Giant dielectric, low dielectric loss, and non-ohmic properties of nanocrystalline $\mathrm{CaCu}_{3} \mathrm{Ti}_{4} \mathrm{O}_{12}$. Journal of Material Science Material in Electronics 24: $3514-3520$

52. Barbier B, Combettes C, Fritsch SG, ChartierT, Rossignol F, et al. (2009) $\mathrm{CaCu}_{3} \mathrm{Ti}_{4} \mathrm{O}_{12}$ ceramics from co-precipitation method: Dielectric Properties of pellets and thick films. Journal of the European Ceramic Society 29(4): 731-735.

53. Thomas P, Dwarakanath K, Varma KBR, Kutty TRN (2008) Nanoparticles of the giant dielectric material, $\mathrm{CaCu}_{3} \mathrm{Ti}_{4} \mathrm{O}_{12}$ from a precursor route. Journal of Physics and Chemistry of Solids 69: 25942604.

54. Marchin L, Fritsch SG, Durand B (2007) Soft chemistry synthesis of the perovskite $\mathrm{CaCu}_{3} \mathrm{Ti}_{4} \mathrm{O}_{12}$. Progress in Solid State Chemistry 36(1-2): 151-155.

55.Zhao Y, Gao R, Su G, Lin H, Wang C, et al. (2013) Effect of dispersanton $\mathrm{CaCu}_{3} \mathrm{Ti}_{4} \mathrm{O}_{12}$ powders synthesized by oxalate co-Precipitation method. Materials Letters 91: 187-190.

56. Sen A, Maiti UN, Maiti S, Chattopadhyay KK (2013) Single crystalline nanostructures of giant dielectric calcium copper titanate: a convenient route toward materialization of hard to realize multicomponent perovskite nanostructures. Journal of Material Science 48: 3967-3974. 
57. Hayashi H, HakutY (2010) Hydrothermal Synthesis of Metal Oxide Nanoparticles in Supercritical Water. Materials 3(7):3794-3817.

58. Keat YC, Sreekantan S, Hutagalung SD, Ahmad ZA (2007) Preparation of $\mathrm{CaCu}_{3} \mathrm{Ti}_{4} \mathrm{O}_{12}$ using a wet chemical method. Journal of Nuclear and Related Technology 4: 53-61.

59.Singh L, Rai US, Mandal KD (2011) Preparation and Characterization of Nanostructured $\mathrm{CaCu}_{2.90} \mathrm{Zn}_{0.10} \mathrm{Ti}_{4} \mathrm{O}_{12}$ Ceramic. Nanomaterials and nanotechnology 1(2): 59-66.

60.Singh L, Rai US, Mandal KD (2013) Dielectric, Modulus and Impedance spectroscopic studies of nanostructured $\mathrm{CaCu}_{2.70} \mathrm{Mg}_{0^{*} 30} \mathrm{Ti}_{4} \mathrm{O}_{12}$ electroceramic synthesized by modified sol-gel route. Journal of Alloys and Compounds 555: 176-183.
61. Mandal KD, Singh L, Sharma S, Rai US, Singh MM (2013) Dielectric and ac impedance studies of nanostructured $\mathrm{CaCu}_{3} \mathrm{Ti}_{3.90} \mathrm{Ce}_{0.10} \mathrm{O}_{12}$ electroceramic synthesized by citrate-gel route. Journal of Sol-Gel Science and Technology 66:50-58.

62. Singh L, Rai US, Mandal KD (2013) Dielectric properties of zinc doped nanocrystalline calcium copper titanate synthesized by different approach. Materials Research Bulletin 48(6): 2117-2122.

63. Singh L, Rai US, Mandal KD, Yashpal M (2012) Dielectric properties of ultrafine $\mathrm{Zn}$-DopedCaCu $\mathrm{Ti}_{4} \mathrm{O}_{12}$. Journal of Advanced Dielectrics 2(1): 1250006-1250007. 